\title{
WILLIAM OUGHTRED
}

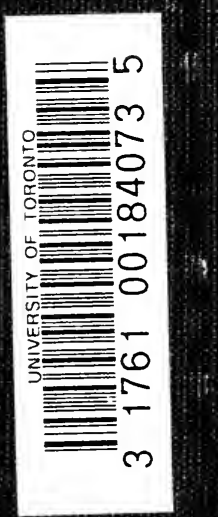

CAJORI 

$\cdot$ 


\section{Digitized by the Internet Archive in 2007 with funding from Microsoft Corporation}


WILLIAM OUGHTRED 



\section{WILLIAM OUGHTRED}

A GREAT SEVENTEENTH-CENTURY

TEACHER OF

\section{MATHEMATICS}

BY

FLORIAN CAJORI, PH.D.

Professor of Mathematics

Colorado College

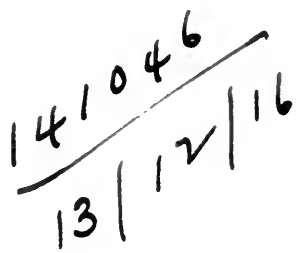

CHICAGO

LONDON

THE OPEN COURT PUBLISHING COMPANY 1916 
Copyright I9I6 By

The Open Court Publishing Co.

All Rights Reserved

Published September I9I6

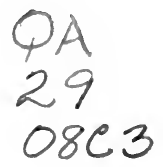

Composed and Printed By The University of Chicago Press Chicago, Illinols, U.S.A. 


\section{TABLE OF CONTENTS}

INTRODUCTION

CHAPTER

I. Oughtred's Life . . . . . . . . . . 3

At School and University . . . . . . . 3

As Rector and Amateur Mathematician . . . 6

His Wife . . . . . . . . . . . . . 7

In Danger of Sequestration . . . . . . 8

His Teaching . . . . . . . . . . . . 9

Appearance and Habits . . . . . . . . $\quad$ I2

Alleged Travel Abroad . . . . . . . . I4

His Death . . . . . . . . . . . I5

II. Principal Works . . . . . . . . . .

Clavis mathematicae . . . . . . . . . I7

Circles of Proportion and Trigonometrie . . . 35

Solution of Numerical Equations . . . . . 39

Logarithms . . . . . . . . . . . 46

Invention of the Slide Rule; Controversy on

Priority of Invention . . . . . . . 46

III. MINOR WORKS . . . . . . . . . . 50

IV. Oughtred's Influence upon Mathematical ProgRESS AND TeAching . . . . . . . 57

Oughtred and Harriot . . . . . . . 57

Oughtred's Pupils . . . . . . . . . . $\quad 5^{8}$

Oughtred, the "Todhunter of the Seventeenth

Century" . . . . . . . . . . . 60

Was Descartes Indebted to Oughtred ? . . . 69

The Spread of Oughtred's Notations . . . . 73 
V. Oughtred's Ideas on the Teaching of MatheMATICS . • . . . . . . . . . 84 General Statement . . . . . . . . 84 Mathematics, "a Science of the Eye" . . . 85 Rigorous Thinking and the Use of Instruments . 87 Newton's Comments on Oughtred . . . 94

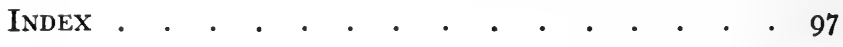




\section{INTRODUCTION}

In the year I660 the Royal Society was founded by royal favor in London, although in reality its inception took place in 1645 when the Philosophical Society (or, as Boyle called it, the "Invisible College") came into being, which held meetings at Gresham College in London and later in Oxford. It was during the second half of the seventeenth century that Sir Isaac Newton, surrounded by a group of great men-Wallis, Hooke, Barrow, Halley, Cotes-carried on his epoch-making researches in mathematics, astronomy, and physics. But it is not this halfcentury of science in England, nor any of its great men, that especially engage our attention in this monograph. It is rather the half-century preceding, an epoch of preparation, when in the early times of the House of Stuart the sciences began to flourish in England. Says Dr. A. E. Shipley: "Whatever were the political and moral deficiencies of the Stuart kings, no one of them lacked intelligence in things artistic and scientific." It was at this time that mathematics, and particularly algebra, began to be cultivated with greater zeal, when elementary algebra with its symbolism as we know it now began to take its shape.

Biographers of Sir Isaac Newton make particular mention of five mathematical books which he read while a young student at Cambridge, namely, Euclid's Elements, Descartes's Géométrie, Vieta's Works, Van Schooten's Miscellanies, and Oughtred's Clavis mathematicae. The last of these books has been receiving increasing attention 
from the historians of algebra in recent years. We have prepared this sketch because we felt that there were points of interest in the life and activity of Oughtred which have not received adequate treatment. Historians have discussed his share in the development of symbolic algebra, but some have fallen into errors, due to inability to examine the original editions of Oughtred's Clavis mathematicae, which are quite rare and inaccessible to most readers. Moreover, historians have failed utterly to recognize his inventions of mathematical instruments, particularly the slide rule; they have completely overlooked his educational views and his ideas on mathematical teaching. The modern reader may pause with profit to consider briefly the career of this interesting man.

Oughtred was not a professional mathematician. $\mathrm{He}$ did not make his livelihood as a teacher of mathematics or as a writer, nor as an engineer who applies mathematics to the control and use of nature's forces. Oughtred was by profession a minister of the gospel. With him the study of mathematics was a side issue, a pleasure, a recreation. Like the great French algebraist, Vieta, from whom he drew much of his inspiration, he was an amateur mathematician. The word "amateur" must not be taken here in the sense of superficial or unthorough. Great Britain has had many men distinguished in science who pursued science as amateurs. Of such men Oughtred is one of the very earliest.

F. C. 


\section{CHAPTER I}

\section{OUGHTRED'S LIFE}

\section{AT SCHOOL AND UNIVERSITY}

William Oughtred, or, as he sometimes wrote his name, Owtred, was born at Eton, the seat of Eton College, the year of his birth being variously given as 1573,1574 , and 1575. "His father," says Aubrey, "taught to write at Eaton, and was a scrivener; and understood common arithmetique, and 'twas no small helpe and furtherance to his son to be instructed in it when a schoole-boy." He was a boy at Eton in the year of the Spanish Armada. At this famous school, which prepared boys for the universities, young Oughtred received thorough training in classical learning.

According to information received from F. L. Clarke, Bursar and Clerk of King's College, Cambridge, Oughtred was admitted at King's a scholar from Eton on September I, I 592, at the age of seventeen. He was made Fellow at King's on September I, I 595, while Elizabeth was still on the throne. He received in 1596 the degree of Bachelor of Arts and in I60o that of Master of Arts. He vacated his fellowship about the beginning of August, r6o3. His career at the University of Cambridge we present in his own words. He says:

Next after Eaton schoole, I was bred up in Cambridge in Kings Colledge: of which society I was a member about eleven or twelve yeares: wherein how I behaved my selfe, going hand in hand with the rest of my ranke in the ordinary Academicall

${ }^{x}$ Aubrey's Brief Lives, ed. A. Clark, Vol. II, Oxford, I898, p. Io6. 
studies and exercises, and with what approbation, is well knowne and remembered by many: the time which over and above those usuall studies I employed upon the Mathematicall sciences, I redeemed night by night from my naturall sleep, defrauding my body, and inuring it to watching, cold, and labour, while most others tooke their rest. Neither did I therein seek only my private content, but the benefit of many: and by inciting, assisting, and instructing others, brought many into the love and study of those Arts, not only in our own, but in some other Colledges also: which some at this time (men far better than my selfe in learning, degree, and preferment) will most lovingly acknowledge. ${ }^{x}$

These words describe the struggles which every youth not endowed with the highest genius must make to achieve success. They show, moreover, the kindly feeling toward others and the delight he took throughout life in assisting anyone interested in mathematics. Oughtred's passion for this study is the more remarkable as neither at Eton nor at Cambridge did it receive emphasis. Even after his time at Cambridge mathematical studies and their applications were neglected there. Jeremiah Horrox was at Cambridge in r633-35, desiring to make himself an astronomer.

"But many impediments," says Horrox, "presented themselves: the tedious difficulty of the study itself deterred a mind not yet formed; the want of means oppressed, and still oppresses, the aspirations of my mind: but that which gave me

" "To the English Gentrie, and all others studious of the Mathematicks, which shall bee Readers hereof. The just Apologie of Wil: Ovghtred, against the slaunderous insimulations of Richard Delamain, in a Pamphlet called Grammelogia, or the Mathematicall Ring, or Mirifica logarithmorum projectio circularis" [I633?], p. 8. Hereafter we shall refer to this pamphlet as the Apologeticall Epistle, this name appearing on the page-headings. 
most concern was that there was no one who could instruct me in the art, who could even help my endeavours by joining me in the study; such was the sloth and languor which had seized all. . . . . I found that books must be used instead of teachers."

Some attention was given to Greek mathematicians, but the works of Italian, German, and French algebraists of the latter part of the sixteenth and beginning of the seventeenth century were quite unknown at Cambridge in Oughtred's day. It was part of his life-work as a mathematician to make algebra, as it was being developed in his time, accessible to English youths.

At the age of twenty-three Oughtred invented his Easy Way of Delineating Sun-Dials by Geometry, which, though not published until about half a century later, in the first English edition of Oughtred's Clavis mathematicae in 1647 , was in the meantime translated into Latin by Christopher Wren, then a Gentleman Commoner of Wadham College, Oxford, now best known through his architectural creations. In I600 Oughtred wrote a monograph on the construction of sun-dials upon a plane of any inclination, but that paper was withheld by him from publication until 1632. Sundials were interesting objects of study, since watches and pendulum clocks were then still unknown. All sorts of sun-dials, portable and non-portable, were used at that time and long afterward. Several of the college buildings at Oxford and Cambridge have sun-dials even at the present time.

${ }^{2}$ Companion to the [British] Almanac of 1837, p. 28 , in an article by Augustus De Morgan on "Notices of English Mathematical and Astronomical Writers between the Norman Conquest and the Year I600." 
AS RECTOR AND AMATEUR MATHEMATICAN

It was in 1604 that Oughtred entered upon his professional life-work as a preacher, being instituted to the vicarage of Shalford in Surrey. In I6 Io he was made rector of Albury, where he spent the remainder of his long life. Since the era of the Reformation two of the rectors of Albury obtained great celebrity from their varied talents and acquirements-our William Oughtred and Samuel Horsley. Oughtred continued to devote his spare time to mathematics, as he had done in college. A great mathematical invention made by a Scotchman soon commanded his attention - the invention of logarithms. An informant writes as follows:

Lord Napier, in 1614, published at Edinburgh his Mirifici logarithmorum canonis descriptio. . . . . It presently fell into the hands of Mr. Briggs, then geometry-reader at Gresham College in London: and that gentleman, forming a design to perfect Lord Napier's plan, consulted Oughtred upon it; who probably wrote his Treatise of Trigonometry about the same time, since it is evidently formed upon the plan of Lord Napier's Canon. ${ }^{x}$

It will be shown later that Oughtred is very probably the author of an "Appendix" which appeared in the 1618 edition of Edward Wright's translation into English of John Napier's Descriptio. This "Appendix" relates to logarithms and is an able document, containing several points of historical interest. Mr. Arthur Hutchinson of Pembroke College informs me that in the university library at Cambridge there is a copy of Napier's Constructio (I6I9) bound up with a copy of Kepler's Chilias logarithmorum (I624), that at the beginning of the Con-

${ }^{x}$ New and General Biographical Dictionary (John Nichols), London, 1784, art. "Oughtred." 
structio is a blank leaf, and before this occurs the titlepage only of Napier's Descriptio (I6I9), at the top of which appears Oughtred's autograph. The history of this interesting signature is unknown.

\section{HIS WIFE}

In 1606 he married Christ'sgift Caryll, daughter of Caryll, Esq., of Tangley, in an adjoining parish. ${ }^{\mathrm{I}} \mathrm{We}$ know very little about Oughtred's family life. The records at King's College, Cambridge, ${ }^{2}$ mention a son, but it is certain that there were more children. A daughter was married to Christopher Brookes. But there is no confirmation of Aubrey's statements, ${ }^{3}$ according to which Oughtred had nine sons and four daughters. Reference to the wife and children is sometimes made in the correspondence with Oughtred. In I6I6 J. Hales writes, "I pray let me be remembered, though unknown, to Mistress Oughtred."4

As we shall see later, Oughtred had a great many young men who came to his house and remained there free of charge to receive instruction in mathematics, which was likewise gratuitous. This being the case, certainly great appreciation was due to Mrs. Oughtred, upon whom the burden of hospitality must have fallen. Yet chroniclers are singularly silent in regard to her. Hers was evidently a life of obscurity and service. We greatly doubt the ${ }^{x}$ Rev. Owen Manning, History of Antiquities in Surrey, Vol. II, p. I32.

${ }^{2}$ Skeleton Collegii Regalis Cantab.: Or A Catalogue of All the Provosts, Fellows and Scholars, of the King's College . . . . since the Foundation Thereof, Vol. II, "William Oughtred."

${ }^{3}$ Aubrey, op. cit., Vol. II, p. I07.

${ }^{4}$ Rigaud, Correspondence of Scientific Men of the Seventeenth Century, Oxford, Vol. I, I84I, p. 5. 
accuracy of the following item handed down by Aubrey; it cannot be a true characterization:

His wife was a penurious woman, and would not allow him to burne candle after supper, by which meanes many a good notion is lost, and many a probleme unsolved; so that $\mathrm{Mr}$. [Thomas] Henshawe, when he was there, bought candle, which was a great comfort to the old man. ${ }^{x}$

\section{IN DANGER OF SEQUESTRATION}

Oughtred spent his years in "unremitted attention to his favourite study," sometimes, it has been whispered, to the neglect of his rectorial duties. Says Aubrey:

I have heard his neighbour ministers say that he was a pittiful preacher; the reason was because he never studyed it, but bent all his thoughts on the mathematiques; but when he was in danger of being sequestred for a royalist, he fell to the study of divinity, and preacht (they sayd) admirably well, even in his old age. ${ }^{2}$

This remark on sequestration brings to mind one of the political and religious struggles of the time, the episcopacy against the independent movements. Says Manning:

In 1646 he was cited before the Committee for Ecclesiastical Affairs, where many articles had been deposed against him; but, by the favour of Sir Bulstrode Whitlock and others, who, at the intercession of William Lilye the Astrologer, appeared in great numbers on his behalf, he had a majority on his side, and so escaped a sequestration. ${ }^{3}$

Not without interest is the account of this matter given by Lilly himself:

About this Time, the most famous Mathematician of all Europe, (Mr. William Oughtred, Parson of Aldbury in Surrey)

s Aubrey, op. cit., Vol. II, p. I 10.

"Ibid., p. III. ${ }^{3}$ Op. cit., Vol. II, p. 132. 
was in Danger of Sequestration by the Committee of or for plunder'd Ministers; (Ambo-dexters they were;) several inconsiderable Articles were deposed and sworn against him, material enough to have sequestred him, but that, upon his Day of hearing, I applied my self to Sir Bolstrode Whitlock, and all my own old Friends, who in such Numbers appeared in his Behalf, that though the Chairman and many other Presbyterian Members were stiff against him, yet he was cleared by the major Number. The truth is, he had a considerable Parsonage, and that only was enough to sequester any moderate Judgment: He was also well known to affect his Majesty [Charles I]. In these Times many worthy Ministers lost their Livings or Benefices, for not complying with the Three-penny Directory. ${ }^{\mathrm{x}}$

\section{HIS TEACHING}

Oughtred had few personal enemies. His pupils held him in highest esteem and showed deep gratitude; only one pupil must be excepted, Richard Delamain. Against him arose a bitter controversy which saddened the life of Oughtred, then an old man. It involved, as we shall see later, the priority of invention of the circular slide rule and of a horizontal instrument or portable sun-dial. In defense of himself, Oughtred wrote in 1633 or 1634 the A pologeticall Epistle, from which we quoted above. This document contains biographical details, in part as follows:

Ever since my departure from the Vniversity, which is about thirty yeares, I have lived neere to the Towne of Guildford in Surrey: where, whether I have taken so much liberly to the losse of time, and the neglect of my calling the whole Countrey thereabout, both Gentry and others, to whom I am full well knowne, will quickely informe him; my house being not past three and twenty miles from London: and yet I so hid my selve at home, that I seldomly travelled so farre as London

${ }^{x}$ Mr. William Lilly's History of His Life and Times, From the Year I602 to I68I, London, I715, p. 58. 
once in a yeare. Indeed the life and mind of man cannot endure without some interchangeablenesse of recreation, and pawses from the intensive actions of our severall callings; and every man is drawne with his owne delight. My recreations have been diversity of studies: and as oft as I was toyled with the labour of my owne profession, I have allayed that tediousnesse by walking in the pleasant and more then Elysian fields of the diverse and various parts of humane learning, and not the Mathematics onely.

Even the opponents of Delamain must be grateful to him for having been the means of drawing from Oughtred such interesting biographical details. Oughtred proceeds to tell how, about 1628 , he was induced to write his Clavis mathematicae, upon which his reputation as a mathematician largely rests:

About five yeares since, the Earle of Arundell my most honourable Lord in a time of his private retiring to his house in the countrey then at West Horsley, foure small miles from me (though since he hath a house in Aldebury the parish where I live) hearing of me (by what meanes I know not) was pleased to send for me: and afterward at London to appoint mee a Chamber of his owne house: where, at such times, and in such manner as it scemed him good to imploy me, and when I might not inconveniently be spared from my charge, I have been most ready to present my selfe in all humble and affectionate service: I hope also without the offence of God, the transgression of the good Lawes of this Land, neglect of my calling, or the deserved scandall of any good man. . . . .

And although I am no mercenary man, nor make profession to teach any one in these arts for gaine and recompence, but as I serve at the Altar, so I live onely of the Altar: yet in those interims that I am at London in my Lords service, I have been still much frequented both by Natives and Strangers, for my resolution and instruction in many difficult poynts of Art; and have most freely and lovingly imparted my selfe and my 
skill, such as I had, to their contentments, and much honourable acknowledgement of their obligation to my Lord for bringing mee to London, hath beene testifyed by many. Of which my liberallity and unwearyed readinesse to doe good to all, scarce any one can give more ample testimony then R. D. himselfe can: would he be but pleased to allay the shame of this his hot and eager contention, blowne up onely with the full bellowes of intended glory and gaine; . . . . they [the subjects in which Delamain received assistance from Oughtred] were the first elements of Astronomie concerning the second motions of the fixed starres, and of the Sunne and Moone; they were the first elements of Conics, to delineate those sections: they were the first elements of Optics, Catoptrics, and Dioptrics: of all which you knew nothing at all.

These last passages are instructive as showing what topics were taken up for study with some of his pupils. The chief subject of interest with most of them wasalgebra, which at that time was just beginning to draw the attention of English lovers of mathematics.

Oughtred carried on an extensive correspondence on mathematical subjects. He was frequently called upon to assist in the solution of knotty problems-sometimes to his annoyance, perhaps, as is shown by the following letter which he wrote in $\mathrm{I} 642$ to a stranger, named Price:

It is true that I have bestowed such vacant time, as I could gain from the study of divinity, (which is my calling,) upon human knowledges, and, amongst other, upon the mathematics, wherein the little skill I have attained, being compared with others of my profession, who for the most part contenting themselves only with their own way, refuse to tread these salebrous and uneasy paths, may peradventure seem the more. But now being in years and mindful of mine end, and having paid dearly for my former delights both in my health and state, 
besides the prejudice of such, who not considering what incessant labour may produce, reckon so much wanting unto me in my proper calling, as they think I have acquired in other sciences; by which opinion (not of the vulgar only) I have suffered both disrespect, and also hinderance in some small perferments I have aimed at. I have therefore now learned to spare myself, and am not willing to descend again in arenam, and to serve such ungrateful muses. Yet, sir, at your request I have perused your problem. .... Your problem is easily wrought per Nicomedis conchoidem lineam. ${ }^{\mathrm{x}}$

\section{APPEARANCE AND HABITS}

Aubrey gives information about the appearance and habits of Oughtred:

He was a little man, had black haire, and blacke eies (with a great deal of spirit). His head was always working. He would drawe lines and diagrams on the dust. . . . .

$\mathrm{He}$ [his oldest son Benjamin] told me that his father did use to lye a bed till eleaven or twelve a clock, with his doublet on, ever since he can remember. Studyed late at night; went not to bed till I I a clock; had his tinder box by him; and on the top of his bed-staffe, he had his inke-horne fix't. He slept but little. Sometimes he went not to bed in two or three nights, and would not come downe to meales till he had found out the quaesitum.

He was more famous abroad for his learning, and more esteemed, then at home. Severall great mathematicians came over into England on purpose to converse with him. His countrey neighbours (though they understood not his worth) knew that there must be extraordinary worth in him, that he was so visited by foreigners. . . . .

When learned foreigners came and sawe how privately he lived, they did admire and blesse themselves, that a person of so much worth and learning should not be better provided for. . . . .

$$
{ }^{2} \text { Rigaud, op. cit., Vol. I, p. } 60 .
$$




\section{Oughtred's Life}

He has told bishop Ward, and Mr. Elias Ashmole (who was his neighbour), that "on this spott of ground" (or "leaning against this oake" or "that ashe"), "the solution of such or such a probleme came into my head, as if infused by a divine genius, after I had thought on it without successe for a yeare, two, or three." . . . .

Nicolaus Mercator, Holsatus . . . . went to see him few yeares before he dyed. . . . .

The right hon ${ }^{\text {ble }}$ Thomas Howard, earle of Arundel and Surrey, Lord High Marshall of England, was his great patron, and loved him intirely. One time they were like to have been killed together by the fall at Albury of a grott, which fell downe but just as they were come out. ${ }^{x}$

Oughtred's friends convey the impression that, in the main, Oughtred enjoyed a comfortable living at Albury. Only once appear indications of financial embarrassment. About I634 one of his pupils, W. Robinson, writes as follows:

I protest unto you sincerely, were I as able as some, at whose hands you have merited exceedingly, or (to speak more absolutely) as able as willing, I would as freely give you $500 \mathrm{l}$. per ann. as 500 pence; and I cannot but be astonished at this our age, wherein pelf and dross is made their summum bonum, and the best part of man, with the true ornaments thereof, science and knowledge, are so slighted. . . . . ${ }^{2}$

In his letters Oughtred complains several times of the limitations for work and the infirmities due to his advancing old age. The impression he made upon others was quite different. Says one biographer:

He sometimes amused himself with archery, and sometimes practised as a surveyor of land. ... . He was sprightly and active, when more than eighty years of age. ${ }^{3}$

${ }^{1}$ Aubrey, op. cit., Vol. II, p. Io7.

${ }^{2}$ Rigaud, op.cit., Vol. I, p. I6. $\quad 3$ Owen Manning, op. cit., p. I32. 
Another informant says that Oughtred was

as facetious in Greek and Latine as solid in Arithmetique, Astronomy, and the sphere of all Measures, Musick, etc.; exact in his style as in his judgment; handling his Cube, and other Instruments at eighty, as steadily, as others did at thirty; owing this, he said, to temperance and Archery; principling his people with plain and solid truths, as he did the world with great and useful Arts; advancing new Inventions in all things but Religion. Which in its old order and decency he maintained secure in his privacy, prudence, meekness, simplicity, resolution, patience, and contentment. ${ }^{I}$

\section{ALLEGED TRAVEL ABROAD}

According to certain sources of information, Oughtred traveled on the European Continent and was invited to change his abode to the Continent. We have seen no statement from Oughtred himself on this matter. He seldom referred to himself in his books and letters. The autobiography contained in his Apologeticall Epistle was written a quarter of a century before his death. Aubrey gives the following:

In the time of the civill warres the duke of Florence invited him over, and offered him 500 li. per annum; but he would not accept it, because of his religion. ${ }^{2}$

A portrait of Oughtred, painted in 1646 by Hollar and inserted in the English edition of the Clavis of 1647 , contains underneath the following lines:

"Haec est Oughtredi senio labantis imago

Itala quam cupiit, Terra Britanna tulit."

In the sketch of Oughtred by Owen Manning it is confessed that "it is not known to what this alludes; but

${ }^{x}$ New and General Biographical Dictionary (John Nichols), London, 1784, art. "Oughtred."

"Op. cit., Vol. II, p. r 10. 
possibly he might have been in Italy with his patron, the Earl of Arundel." I It would seem quite certain either that Oughtred traveled in Europe or that he received some sort of an offer to settle in Italy. In view of Aubrey's explicit statement and of Oughtred's well-known habit of confining himself to his duties and studies in his own parish, seldom going even as far as London, we strongly incline to the opinion that he did not travel on the Continent, but that he received an offer from some patron of the sciences-possibly some distinguished visitor-to settle in Italy.

\section{HIS DEATH}

He died at Albury, June 30, I660, aged about eightysix years. Of his last days and death, Aubrey speaks as follows:

Before he dyed he burned a world of papers, and sayd that the world was not worthy of them; he was so superb. $\mathrm{He}$ burned also severall printed bookes, and would not stirre, till they were consumed..... I myselfe have his Pitiscus, imbelished with his excellent marginall notes, which I esteeme as a great rarity. I wish I could also have got his Bilingsley's Euclid, which John Collins sayes was full of his annotations. . . . .

Ralph Greatrex, his great friend, the mathematicall instrument-maker, sayed he conceived he dyed with joy for the comeing-in of the king, which was the 29th of May before. "And are yee sure he is restored?"- "Then give me a glasse of sack to drinke his sacred majestie's health." His spirits were then quite upon the wing to fly away. . . . ${ }^{2}$

In this passage, as in others, due allowance must be made for Aubrey's lack of discrimination. He was not

${ }^{x}$ Rev. Owen Manning, The History and Antiquities of Surrey, Vol. II, London, I809, p. I32.

${ }^{2}$ Op. cit., Voì. II, I898, p. III. 
in the habit of sifting facts from mere gossip. That Oughtred should have declared that the world was not worthy of his papers or manuscripts is not in consonance with the sweetness of disposition ordinarily attributed to him. More probable was the feeling that the papers he burned-possibly old sermons-were of no particular value to the world. That he did not destroy a large mass of mathematical manuscripts is evident from the fact that a considerable number of them came after his death into the hands of Sir Charles Scarborough, M.D., under whose supervision some of them were carefully revised and published at Oxford in 1677 under the title of Opuscula mathematica hactenus inedita.

Aubrey's story of Oughtred's mode of death has been as widely circulated in every modern biographical sketch as has his slander of Mrs. Oughtred by claiming that she was so penurious that she would deny him the use of candles to read by. Oughtred died on June 30; the Restoration occurred on May 29. No doubt Oughtred rejoiced over the Restoration, but the story of his drinking "a glass of sack" to his Majesty's health, and then dying of joy is surely apocryphal. De Morgan humorously remarks, "It should be added, by way of excuse, that he was eighty-six years old."

${ }^{x}$ Budget of Paradoxes, London, 1872, p. 451; 2d ed., Chicago and London, I915, Vol. II, p. 303. 


\section{CHAPTER II}

\section{PRINCIPAL WORKS \\ "ClAVIS MATHEMATICAE"}

Passing to the consideration of Oughtred's mathematical books, we begin with the observation that he showed a marked disinclination to give his writings to the press. His first paper on sun-dials was written at the age of twenty-three, but we are not aware that more than one brief mathematical manuscript was printed before his fifty-seventh year. In every instance, publication in printed form seems to have been due to pressure exerted by one or more of his patrons, pupils, or friends. Some of his manuscripts were lent out to his pupils, who prepared copies for their own use. In some instances they urged upon him the desirability of publication and assisted in preparing copy for the printer. The earliest and bestknown book of Oughtred was his Clavis mathematicae, to which repeated allusion has already been made. As he himself informs us, he was employed by the Earl of Arundel about 1628 to instruct the Earl's son, Lord William Howard (afterward Viscount Stafford) in the mathematics. For the use of this young man Oughtred composed a treatise on algebra which was published in Latin in the year I63I at the urgent request of a kinsman of the young man, Charles Cavendish, a patron of learning.

The Clavis mathematicae, ${ }^{\mathrm{r}}$ in its first edition of $\mathrm{I} 63 \mathrm{I}$, was a booklet of only 88 small pages. Yet it contained in very

${ }^{1}$ The full title of the Clavis of $\mathrm{I}_{3} \mathrm{I}$ is as follows: Arithmeticae in numeris et speciebvs institvtio: Qvae tvm logisticae, tvm analyticae, 
condensed form the essentials of arithmetic and algebra as known at that time.

Aside from the addition of four tracts, the 163 I edition underwent some changes in the editions of 1647 and 1648 , which two are much alike. The twenty chapters of I63I are reduced to nineteen in 1647 and in all the later editions. Numerous minute alterations from the I63 I edition occur in all parts of the books of 1647 and 1648 . The material of the last three chapters of the 163 I edition is rearranged, with some slight additions here and there. The 1648 edition has no preface. In the print of ${ }_{1} 65_{2}$ there are only slight alterations from the 1648 edition; after that the

atqve adeo totivs mathematicae, qvasi clavis est.-Ad nobilissimvm spectatissimumque invenem Dn. Gvilelmvm Howard, Ordinis qui dicitur, Balnei Equitem, honoratissimi Dn. Thomae, Comitis Arvndeliae E० Svrriae, Comitis Mareschalli Angliae, \&o filium.-Londini, Apud Thomam Harpervm. M.DC.XXXI.

In all there appeared five Latin editions, the second in I648 at London, the third in $165^{2}$ at Oxford, the fourth in 1667 at Oxford, the fifth in 1693 and 1698 at Oxford. There were two independent English editions: the first in 1647 at London, translated in greater part by Robert Wood of Lincoln College, Oxford, as is stated in the preface to the 1652 Latin edition; the second in 1694 and 1702 is a new translation, the preface being written and the book recommended by the astronomer Edmund Halley. The 1694 and 1702 impressions labored under the defect of many sense-disturbing errors due to careless reading of the proofs. All the editions of the Clavis, after the first edition, had one or more of the following tracts added on:

$E q .=$ De Aequationum affectarvm resolvtione in numeris.

$E_{u .}=$ Elementi decimi Euclidis declaratio.

So. $=$ De Solidis regularibus, tractatus.

An. $=$ De Anatocismo, sive usura composita.

$F a .=$ Regula falsae positionis.

Ar. $=$ Theorematum in libris Archimedis de Sphaera \& cylindro declaratio.

IIo. = Horologia scioterica in plano, geometricè delineandi modus.

The abbreviated titles given here are, of course, our own. The lists of tracts added to the Clavis mathematicae of $\mathrm{I}_{3} \mathrm{I}$ in its later 
book underwent hardly any changes, except for the number of tracts appended, and brief explanatory notes added at the close of the chapters in the English editions of r694 and I702. The 1652 and 1667 editions were seen through the press by John Wallis; the 1698 impression contains on the title-page the words: Ex Recognitione D. Johannis Wallis, S.T.D. Geometriae Professoris Saviliani.

The cost of publishing may be a matter of some interest. When arranging for the printing of the 1667 edition of the Clavis, Wallis wrote Collins: "I told you in my last what price she [Mrs. Lichfield] expects for it, as I have formerly understood from her, viz., £ 4 o for the impression, which is about $9 \frac{1}{2} d$. a book."

As compared with other contemporary works on algebra, Oughtred's distinguishes itself for the amount of symbolism used, particularly in the treatment of geometric problems. Extraordinary emphasis was placed upon what he called in the Clavis the "analytical art.""

editions, given in the order in which the tracts appear in each edition,

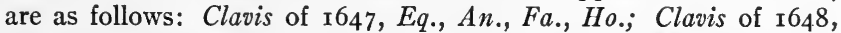
Eq., An., Fa., Eu., So.; Clavis of 1652, Eq., Eu., So., An., Fa., Ar., Ho.; Clavis of $1667, E q .$, Eu., So., An., Fa., Ar., Ho.; Clavis of I693 and 1698, Eq., Eu., So., An., Fa., Ar., Ho.; Clavis of 1694 and I $702, E q$.

The title-page of the Clavis was considerably modified after the first edition. Thus, the $165^{2}$ Latin edition has this title-page: Guilelmi Oughtred Aetonensis, quondam Collegii Regalis in Cantabrigia Socii, Clavis mathematicae denvo limata, sive potius fabricata. Cum aliis quibusdam ejusdem commentationibus, quae in sequenti pagina recensentur. Editio tertia auctior \& emendatior. Oxoniae, Excudebat Leon. Lichfield, Veneunt apud Tho. Robinson. ${ }^{6} 62$.

${ }^{x}$ Rigaud, $o p$. cit., Vol. II, p. 476.

${ }^{2}$ See, for instance, the Clavis mathematicae of $165^{2}$, where he expresses himself thus (p. 4): "Speciosa haec Arithmetica arti Analyticae (per quam ex sumptione quaesiti, tanquam noti, investigatur quaesitum) multo accommodatior est, quam illa numerosa." 
By that term he did not mean our modern analysis or analytical geometry, but the art "in which by taking the thing sought as knowne, we finde out that we seeke." He meant to express by it condensed processes of rigid, logical deduction expressed by appropriate symbols, as contrasted with mere description or elucidation by passages fraught with verbosity. In the preface to the first edition ( $163 \mathrm{I}$ ) he says:

In this little book I make known . . . . the rules relating to fundamentals, collected together, just like a bundle, and adapted to the explanation of as many problems as possible.

As stated in this preface, one of his reasons for publishing the book, is

. . . . that like Ariadne I might offer a thread to mathematical study by which the mysteries of this science might be revealed, and direction given to the best authors of antiquity, Euclid, Archimedes, the great geometrician Apollonius of Perga, and others, so as to be easily and thoroughly understood, their theorems being added, not only because to many they are the height and depth of mathematical science (I ignore the would-be mathematicians who occupy themselves only with the so-called practice, which is in reality mere juggler's tricks with instruments, the surface so to speak, pursued with a disregard of the great art, a contemptible picture), but also to show with what keenness they have penetrated, with what mass of equations, comparisons, reductions, conversions and disquisitions these heroes have ornamented, increased and invented this most beautiful science.

The Clavis opens with an explanation of the HinduArabic notation and of decimal fractions. Noteworthy is the absence of the words "million," "billion," etc. Though used on the Continent by certain mathematical writers long before this, these words did not become current in

'Oughtred, The Key of the Mathematicks, London, 1647, p. 4. 
English mathematical books until the eighteenth century. The author was a great admirer of decimal fractions, but failed to introduce the notation which in later centuries came to be universally adopted. Oughtred wrote 0.56 in this manner o 56 ; the point he used to designate ratio. Thus 3:4 was written by him $3 \cdot 4$. The decimal point (or comma) was first used by the inventor of logarithms, John Napier, as early as I6I6 and I6I 7 . Although Oughtred had mastered the theory of logarithms soon after their publication in 1614 and was a great admirer of Napier, he preferred to use the dot for the designation of ratio. This notation of ratio is used in all his mathematical books, except in two instances. The two dots (:) occur as symbols of ratio in some parts of Oughtred's posthumous work, Opuscula mathematica hactenus inedita, Oxford, 1677 , but may have been due to the editors and not to Oughtred himself. Then again the two dots (:) are used to designate ratio on the last two pages of the tables of the Latin edition of Oughtred's Trigonometria of $\mathrm{r} 657$. In all other parts of that book the $\operatorname{dot}(\cdot)$ is used. Probably someone who supervised the printing of the tables introduced the (:) on the last two pages, following the logarithmic tables, where methods of interpolation are explained. The probability of this conjecture is the stronger, because in the English edition of the Trigonometrie, brought out the same year ( $\mathrm{I}_{57}$ ) but after the Latin edition, the notation (:) at the end of the book is replaced by the usual $(\cdot)$, except that in some copies of the English edition the explanations at the end are omitted altogether.

Oughtred introduces an interesting, and at the same time new, feature of an abbreviated multiplication and an abbreviated division of decimal fractions. On this point 
he took a position far in advance of his time. The part on abbreviated multiplication was rewritten in slightly enlarged form and with some unimportant alterations in the later edition of the Clavis. We give it as it occurs in the revision. Four cases are given. In finding the product of $246 \mid 9{ }^{14}$ and $35 \mid 27$, "if you would have the Product without any Parts" (without any decimal part), "set the place of Unity of the lesser under the place of Unity in the greater: as in the Example," writing the figures of the lesser number in inverse order. From the example it will be seen that he begins by multiplying by 3 , the right-hand digit of the multiplier. In the $87 \circ 8$ first edition of the Clavis he began with 7 , the left digit. Observe also that he "carries" the nearest tens in the product of each lower digit and the upper digit one place to its right. For instance, he takes $7 \times 4=28$ and carries 3 , then he finds $7 \times 2+3=17$ and writes down 17 .

The second case supposes that "you would have the Product with some places of parts" (decimals), say 4: "Set the place of Unity of the lesser Number under the Fourth place of the Parts of the greater." The multiplication of $246 \mid 914$ by $35 \mid 27$ is now performed thus:

$$
\begin{aligned}
& 246 \lcm{9 \text { I } 4} \\
& 7253 \\
& 74074200 \\
& \text { I } 2345700 \\
& 493828 \\
& \text { I } 7284 \text { O } \\
& 87 \circ 86568
\end{aligned}
$$


In the third and fourth cases are considered factors which appear as integers, but are in reality decimals; for instance, the sine of $54^{\circ}$ is given in the tables as 80902 when in reality it is .80902 .

Of interest as regards the use of the word "parabola" is the following: "The Number found by Division is called the Quotient, or also Parabola, because it arises out of the Application of a plain Number to a given Longitude, that a congruous Latitude may be found." ${ }^{\prime}$ This is in harmony with etymological dictionaries which speak of a parabola as the application of a given area to a given straight line. The dividend or product is the area; the divisor or factor is the line.

Oughtred gives two processes of long division. The first is identical with the modern process, except that the divisor is written below every remainder, each digit of the divisor being crossed out as soon as it has been used in the partial multiplication. The second method of long division is one of the several types of the old "scratch method." This antiquated process held its place by the side of the modern method in all editions of the Clavis. The author divides 467023 by $357 / 0926425$, giving the following instructions: "Take as many of the first Figures of the Divisor as are necessary, for the first Divisor, and then in every following particular Division drop one of the Figures of the Divisor towards the Left Hand, till you have got a competent Quotient." He does not explain abbreviated division as thoroughly as abbreviated multiplication.

${ }^{x}$ Clavis 1694, p. 19, and the Clavis of $\mathrm{r} 63 \mathrm{r}$, p. 8. 


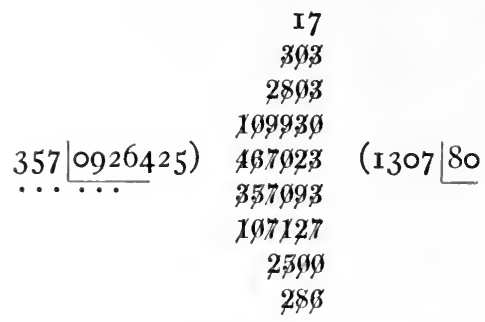

Oughtred does not examine the degree of reliability or accuracy of his processes of abbreviated multiplication and division. Here as in other places he gives in condensed statement the mode of procedure, without further discussion.

He does not attempt to establish the rules for the addition, subtraction, multiplication, and division of positive and negative numbers. "If the Signs are both alike, the Product will be affirmative, if unlike, negative"; then he proceeds to applications. This attitude is superior to that of many writers of the eighteenth and nineteenth centuries, on pedagogical as well as logical grounds: pedagogically, because the beginner in the study of algebra is not in a position to appreciate an abstract train of thought, as every teacher well knows, and derives better intellectual exercise from the applications of the rules to problems; logically, because the rule of signs in multiplication does not admit of rigorous proof, unless some other assumption is first made which is no less arbitrary than the rule itself. It is well known that the proofs of the rule of signs given by eighteenth-century writers are invalid. Somewhere they involve some surreptitious assumption. This criticism applies even to the proof given by Laplace, which tacitly assumes the distributive law in multiplication. 


\section{Principal Works}

A word should be said on Oughtred's definition of + and - . He recognizes their double function in algebra by saying (Clavis, I63I, p. 2): "Signum additionis, sive affirmationis, est + plus" and "Signum subductionis, sive negationis est - minus." They are symbols which indicate the quality of numbers in some instances and operations of addition or subtraction in other instances. In the I694 edition of the Clavis, thirty-four years after the death of Oughtred, these symbols are defined as signifying operations only, but are actually used to signify the quality of numbers as well. In this respect the 1694 edition marks a recrudescence.

The characteristic in the Clavis that is most striking to a modern reader is the total absence of indexes or exponents. There is much discussion in the leading treatises of the latter part of the sixteenth and the early part of the seventeenth century on the theory of indexes, but the modern exponential notation, $a^{n}$, is of later date. The modern notation, for positive integral exponents, first appears in Descartes' Géométrie, I637; fractional and negative exponents were first used in the modern form by Sir Isaac Newton, in his announcement of the binomial formula, in a letter written in 1676 . This total absence of our modern exponential notation in Oughtred's Clavis gives it a strange aspect. Like Vieta, Oughtred uses ordinarily the capital letters, $A, B, C, \ldots$ to designate given numbers; $A^{2}$ is written $A q, A^{3}$ is written $A c$; for $A^{4}, A^{5}, A^{6}$ he has, respectively, $A q q, A q c, A c c$. Only on rare occasions, usually when some parallelism in notation is aimed at, does he use small letters ${ }^{x}$ to represent numbers or magnitudes. Powers of binomials or polynomials

' See for instance, Oughtred's Elementi decimi Euclidis declaratio, 1652, p. r, where he uses $A$ and $E$, and also $a$ and $e$. 
are marked by prefixing the capital letters $Q$ (for square), $C$ (for cube), $Q Q$ (for the fourth power), $Q C$ (for the fifth power), etc.

Oughtred does not express aggregation by (). Parentheses had been used by Girard, and by Clavius as early as $1609,{ }^{x}$ but did not come into general use in mathematical language until the time of Leibniz and the Bernoullis. Oughtred indicates aggregation by writing a colon $(:)$ at both ends. Thus, $Q: A-E$ :means with him $(A-E)^{2}$. Similarly, $\vee q: A+E$ : means $\gamma(A+E)$. The two dots at the end are frequently omitted when the part affected includes all the terms of the polynomial to the end. Thus, $C: A+B-E=\ldots$ means $(a+B-E)^{3}=\ldots$ There are still further departures from this notation, but they occur so seldom that we incline to the interpretation that they are simply printer's errors. For proportion Oughtred uses the symbol (::). The proportion $a: b=$ $c: d$ appears in his notation $a \cdot b:: c \cdot d$. Apparently, a proportion was not fully recognized in this day as being the expression of an equality of ratios. That probably explains why he did not use $=$ here as in the notation of ordinary equations. Yet Oughtred must have been very close to the interpretation of a proportion as an equality; for he says in his Elementi decimi Euclidis declaratio, "proportio, sive ratio aequalis ::" That he introduced this extra symbol when the one for equality was sufficient is a misfortune. Simplicity demands that no unnecessary symbols be introduced. However, Oughtred's symbolism is certainly superior to those which preceded. Consider the notation of Clavius. ${ }^{2}$ He wrote $20: 60=4: x, x=12$,

${ }^{x}$ See Christophori Clavii Bambergensis Operum mathematicorum, tomus secundus, Moguntiae, M.DC.XI, algebra, p. 39.

${ }^{2}$ Christophori Clavii operum mathematicorum Tomus Sccundus, Moguntiae, M.DC.XI, Epitome arillmeticae, p. 36. 
thus: " $20 \cdot 60 \cdot 4$ ? fiunt $\mathrm{I} 2$. ." The insufficiency of such a notation in the more involved expressions frequently arising in algebra is readily seen. Hence Oughtred's notation (::) was early adopted by English mathematicians. It was used by John Wallis at Oxford, by Samuel Foster at Gresham College, by James Gregory of Edinburgh, by the translators into English of Rahn's algebra, and by many other early writers. Oughtred has been credited generally with the introduction of St. Andrew's cross $X$ as the symbol for multiplication in the Clavis of I63I. We have discovered that this symbol, or rather the letter $x$ which closely resembles it, occurs as the sign of multiplication thirteen years earlier in an anonymous "Appendix to the Logarithmes, shewing the practise of the Calculation of Triangles etc." to Edward Wright's translation of John Napier's Descriptio, published in $1618 .{ }^{x}$ Later we shall give our reasons for believing that Oughtred is the author of that "Appendix." The $X$ has survived as a symbol of multiplication.

Another symbol introduced by Oughtred and found in modern books is $\sim$, expressing difference; thus $C \backsim D$ signifies the difference between $C$ and $D$, even when $D$ is the larger number. ${ }^{2}$ This symbol was used by John Wallis in 1657.3

Oughtred represented in symbols also certain composite expressions, as for instance $A+E=Z, A-E=X$, where $A$ is greater than $E$. He represented by a symbol also each of the following: $A^{2}+E^{2}, A^{3}+E^{3}, A^{2}-E^{2}$, $A^{3}-E^{3}$.

${ }^{x}$ See F. Cajori, "The Cross $X$ as a Symbol of Multiplication," in Nature, Vol. XCIV (1914), p. 363.

${ }^{2}$ See Elementi decimi Euclidis declaratio, 1652, p. 2.

${ }^{3}$ See Johannis Wallisii Operum mathematicorum pars prima, Oxonii, r657, p. 247. 
Oughtred practically translated the tenth book of Euclid from its ponderous rhetorical form into that of brief symbolism. An appeal to the eye was a passion with Oughtred. The present writer has collected the different mathematical symbols used by Oughtred and has found more than one hundred and fifty of them.

The differences between the seven different editions of the Clavis lie mainly in the special parts appended to some editions and dropped in the latest editions. The part which originally constituted the Clavis was not materially altered, except in two or three of the original twenty chapters. These changes were made in the editions of I647 and I648. After the first edition; great stress was laid upon the theory of indices upon the very first page, as also in passages farther on. Of course, Oughtred did not have our modern notation of indices or exponents, but their theory had been a part of algebra and arithmetic for some time. Oughtred incorporated this theory in his brief exposition of the Hindu-Arabic notation and in his explanation of logarithms. As previously pointed out, the last three chapters of the r63r edition were considerably rearranged in the later editions and combined into two chapters, so that the Clavis proper had nineteen chapters instead of twenty in the additions after the first. These chapters consisted of applications of algebra to geometry and were so framed as to constitute a severe test of the student's grip of the subject. The very last problem deals with the division of angles into equal parts. He derives the cubic equation upon which the trisection depends algebraically, also the equations of the fifth degree and seventh degree upon which the divisions of the angle into 5 and 7 equal parts depend, respectively. The exposition was severely brief, yet accurate. He did not 
believe in conducting the reader along level paths or along slight inclines. He was a guide for mountain-climbers, and woe unto him who lacked nerve.

Oughtred lays great stress upon expansions of powers of a binomial. He makes use of these expansions in the solution of numerical equations. To one who does not specialize in the history of mathematics such expansions may create surprise, for did not Newton invent the binomial theorem after the death of Oughtred? As a matter of fact, the expansions of positive integral powers of a binomial were known long before Newton, not only to seventeenth-century but even to eleventh-century mathematicians. Oughtred's Clavis of I63I gave the binomial coefficients for all powers up to and including the tenth. What Newton really accomplished was the generalization of the binomial expansion which makes it applicable to negative and fractional exponents and converts it into an infinite series.

As a specimen of Oughtred's style of writing we quote his solution of quadratic equations, accompanied by a translation into English and into modern mathematical symbols.

As a preliminary step ${ }^{x}$ he lets

$$
Z=A+E \text { and } A>E ;
$$

he lets also $X=A-E$. From these relations he obtains identities which, in modern notation, are $\frac{1}{4} Z^{2}-A E=$ $\left(\frac{1}{2} Z-E\right)^{2}=\frac{1}{4} X^{2}$. Now, if we know $Z$ and $A E$, we can find $\frac{1}{2} X$. Then $\frac{1}{2}(Z+X)=A$, and $\frac{1}{2}(Z-X)=E$, and

$$
A=\frac{1}{2} Z+\sqrt{\frac{1}{4} Z^{2}-A E} .
$$

${ }^{x}$ Clavis of $163 \mathrm{r}$, chap. xix, sec. 5 , p. 50. 
Having established these preliminaries, he proceeds thus:

Datis igitur linea inaequaliter secta $Z$ (Iо), \& rectangulo sub segmentis $A E$ (2I) qui gnomon est: datur semidifferentia segmentorum $\frac{1}{2} X$ : \& per consequens ipsa segmenta. Nam ponatur alterutrum segmentum $A$ : alterum erit $Z-A$ : Rectangulum auctem est $Z A-A_{q}=A E$. Et quia dantur $Z$ \& $A E$ : estque $\frac{1}{4} Z_{q}-A E=\frac{1}{4} X_{q}$ : \& per 5 c. $18, \frac{1}{2} Z+\frac{1}{2} X=A$ : \& $\frac{1}{2} Z-\frac{1}{2} X=E$ : Aequatio sic resoluetur: $\frac{1}{2} Z \pm \sqrt{ }_{q}: \frac{1}{4} Z_{q}-A E$ : $=A\left\{\begin{array}{l}\text { maius segment } \\ \text { minus segment. }\end{array}\right.$

Itaque proposita equatione, in qua sunt tres species aequaliter in ordine tabellae adscendentes, altissima autem species ponitur negata: Magnitudo data coefficiens mediam speciem est linea bisecanda: \& magnitudo absoluta data, ad quam sit aequatio, est rectangulum sub segmentis inaequalibus, sine gnomon: vt $Z A-A_{q}=A E$ : in numeris autem rol- $l_{q}=2 \mathrm{I}$ : Estque $A$, vel $\mathrm{r} l$, alterutrum segmentum inaequale. Inuenitur autem sic:

Dimidiata coefficiens median speciem est $\frac{Z}{2}(5)$; cuius quadratum est $\frac{Z_{q}}{4}$ (25): ex hoc tolle $A E$ (2I) absolutum: eritque $\frac{Z_{q}}{4}-A E$ (4) quadratum semidifferentiae segmentorum: latus huius quadratum $\vee_{q}: \frac{Z_{q}}{4}-A E(2)$ est semidifferentia: quam si addas ad $\frac{Z}{2}(5)$ semissem coefficientis, sive lineae bisecandae, erit maius segment.; sin detrahas, erit minus segment: Dico $\frac{Z}{2} \pm V_{q}: \frac{Z_{q}}{4}-A E:=A\left\{\begin{array}{l}\text { maius segmentum } \\ \text { minus segmentum. }\end{array}\right.$

We translate the Latin passage, nsing the modern exponential notation and parentheses, as follows:

Given therefore an unequally divided line $Z$ (Io), and a rectangle beneath the segments $A E(2 \mathrm{I})$ which is a gnomon. 
Half the difference of the segments $\frac{1}{2} X$ is given, and consequently the segment itself. For, if one of the two segments is placed equal to $A$, the other will be $Z-A$. Moreover, the rectangle is $Z A-A^{2}=A E$. And because $Z$ and $A E$ are given, and there is $\frac{1}{4} Z^{2}-A E=\frac{1}{4} X^{2}$, and by $5 c \cdot 18, \frac{1}{2} Z+\frac{1}{2} X=A$, and $\frac{1}{2} Z-\frac{1}{2} X=E$, the equation will be solved thus: $\frac{1}{2} Z \pm \sqrt{ }\left(\frac{1}{4} Z^{2}-\right.$ $A E)=A\left\{\begin{array}{l}\text { major segment } \\ \text { minor segment. }\end{array}\right.$

And so an equation having been proposed in which three species (terms) are in equally ascending powers, the highest species, moreover, being negative, the given magnitude which constitutes the middle species is the line to be bisected. And the given absolute magnitude to which it is equal is the rectangle beneath the unequal segments, without gnomon. As $Z A-A^{2}=A E$, or in numbers, Io $x-x^{2}=2 \mathrm{I}$. And $A$ or $x$ is one of the two unequal segments. It may be found thus:

The half of the middle species is $\frac{Z}{2}(5)$, its square is $\frac{Z^{2}}{4}(25)$. From it subtract the absolute term $A E$ (2I), and $\frac{Z_{2}^{2}}{4}-A E(4)$ will be the square of half the difference of the segments. The square root of this, $V\left[\left(\frac{Z^{2}}{2}\right)^{2}-A E\right](2)$, is half the difference. If you add it to half the coefficient $\frac{Z}{2}(5)$, or half the line to be bisected, the longer segment is obtained; if you subtract it, the smaller segment is obtained. I say:

$$
\frac{Z}{2} \pm \sqrt{ }\left(\frac{Z^{2}}{4}-A E\right)=A\left\{\begin{array}{l}
\text { major segment } \\
\text { minor segment. }
\end{array}\right.
$$

The quadratic equation $A q+Z A=A E$ receives similar treatment. This and the preceding equation, $Z A-A q=$ $A E$, constitute together a solution of the general quadratic equation, $x^{2}+a x=b$, provided that $E$ or $Z$ are not restricted to positive values, but admit of being either 
positive or negative, a case not adequately treated by Oughtred. Imaginary numbers and imaginary roots receive no consideration whatever.

A notation suggested by Vieta and favored by Girard made vowels stand for unknowns and consonants for knowns. This conventionality was adopted by Oughtred in parts of his algebra, but not throughout. Near the beginning he used $Q$ to designate the unknown, though usually this letter stood with him for the "square" of the expression after it. ${ }^{\mathrm{I}}$

It is of some interest that Oughtred used $\frac{\pi}{\delta}$ to signify the ratio of the circumference to the diameter of a circle. Very probably this notation is the forerunner of the $\pi=$ 3. I4I59 ... used in I706 by William Jones. Oughtred first used $\frac{\pi}{\delta}$ in the 1647 edition of the Clavis mathematicae. In the $1_{5} 2$ edition he says, "Si in circulo sit 7.22:: $\delta \cdot \pi::$ II $3 \cdot 355$ : erit $\delta \cdot \pi:: 2$ R.P: periph." This notation was adopted by Isaac Barrow, who used it extensively. David Gregory ${ }^{2}$ used $\frac{\pi}{\rho}$ in 1697 , and De Moivre ${ }^{3}$ used $\frac{c}{r}$ about 1697 , to designate the ratio of the circumference to the radius.

I We have noticed the representation of known quantities by consonants and the unknown by vowels in Wingate's Arithmetick made casie, edited by John Kersey, London, I650, algebra, p. 382; and in the second part, section 19, of Jonas Moore's Arithmetick in two parts, London, I660, Moore suggests as an alternative the use of $z, y, x$, etc., for the unknowns. The practice of representing unknowns by vowels did not spread widely in England.

${ }^{2}$ Philosophical Transactions, Vol. XIX, No. 23I, London, p. 652.

${ }^{3}$ Ibid., Vol. XIX, p. 56. 
We quote the description of the Clavis that was given by Oughtred's greatest pupil, John Wallis. It contains additional information of interest to us. Wallis devotes chap. xv of his Treatise of Algebra, London, I685, pp. 6769, to Mr. Oughtred and his Clavis, saying:

Mr. William Oughtred (our Country-man) in his Clavis Mathematicae, (or Key of Mathematicks,) first published in the Year I63I, follows Vieta (as he did Diophantus) in the use of the Cossick Denominations; omitting (as he had done) the names of Sursolids, and contenting himself with those of Square and $C u b e$, and the Compounds of these.

But he doth abridge Vieta's Characters or Species, using only the letters q, c, \&c. which in Vieta are expressed (at length) by Quadrate, Cube, \&c. For though when Vieta first introduced this way of Specious Arithmetick, it was more necessary (the thing being new,) to express it in words at length: Yet when the thing was once received in practise, Mr. Oughtred (who affected brevity, and to deliver what he taught as briefly as might be, and reduce all to a short view,) contented himself with single Letters instead of those words.

Thus what Vieta would have written

$$
\frac{A \text { Quadrate, into B Cube, }}{C D E \text { Solid, }} \text { Equal to FG Plane, }
$$

would with him be thus expressed

$$
\frac{A_{q} B_{c}}{C D E}=F G .
$$

And the better to distinguish upon the first view, what quantities were Known, and what Unknown, he doth (usually) denote the Known to Consonants, and the Unknown by Vowels; as Vieta (for the same reason) had done before him.

He doth also (to very great advantage) make use of several Ligatures, or Compendious Notes, to signify Summs, Differences, and Rectangles of several Quantities. As for instance, 
Of two Quantities A (the Greater), and E (the Lesser), the Sum he calls $\mathrm{Z}$, the Difference $\mathrm{X}$, the Rectangle AE. . . . .

Which being of (almost) a constant signification with him throughout, do save a great circumlocution of words, (each Letter serving instead of a Definition;) and are also made use of (with very great advantage) to discover the true nature of divers intricate Operations, arising from the various compositions of such Parts, Sums, Differences, and Rectangles; (of which there is great plenty in his Clavis, Cap. I I, I6, I8, I9. and elsewhere,) which without such Ligatures, or Compendious Notes, would not be easily discovered or apprehended. . . . .

I know there are who find fault with his Clavis, as too obscure, because so short, but without cause; for his words be always full, but not Redundant, and need only a little attention in the Reader to weigh the force of every word, and the Syntax of it; ..... And this, when once apprehended, is much more easily retained, than if it were expressed with the prolixity of some other Writers; where a Reader must first be at the pains to weed out a great deal of superfluous Language, that he may have a short prospect of what is material; which is here contracted for him in a short Synopsis. . . . .

Mr. Oughtred in his Clavis, contents himself (for the most part) with the solution of Quadratick Equations, without proceeding (or very sparingly) to Cubick Equations, and those of Higher Powers; having designed that Work for an Introduction into Algebra so far, leaving the Discussion of Superior Equations for another work. . . . . He contents himself likewise in Resolving Equations, to take notice of the Affirmative or Positive Roots; omitting the Negative or Ablative Roots, and such as are called Imaginary or Impossible Roots. And of those which, he calls Ambiguous Equations, (as having more Affirmative Roots than one,) he doth not (that I remember) any where take notice of more than Two Affirmative Roots: (Because in Quadratick Equations, which are those he handleth, there are indeed no more.) Whereas yet in Cubick Equations, there may be Three, and in those of Higher Powers, yet more. Which 
Vieta was well aware of, and mentioneth in some of his Writings; and of which Mr. Oughtred could not be ignorant.

\section{"CIRCLES OF PROPORTION" AND "TRIGONOMETRIE"}

Oughtred wrote and had published three important mathematical books, the Clavis, the Circles of Proportion, ${ }^{\mathrm{I}}$ and a Trigonometrie. ${ }^{2}$ This last appeared in the year 1657 at London, in both Latin and English.

It is claimed that the trigonometry was "neither finished nor published by himself, but collected out of his scattered papers; and though he connived at the printing it, yet imperfectly done, as appears by his MSS.; and one of the printed Books, corrected by his own

${ }^{I}$ There are two title-pages to the edition of $\mathrm{I}_{632}$. The first titlepage is as follows: The Circles of Proportion and The Horizontall Instrument. Both invented, and the vses of both Written in Latine by Mr.W.O. Translated into English: and set forth for the publique benefit by William Forster. London. Printed for Elias Allen maker of these and all other mathematical Instruments, and are to be sold at his shop over against St. Clements church with out Temple-barr. ${ }_{16}{ }_{32}$. T. Cecill Sculp.

In 1633 there was added the following, with a separate title-page: An addition vnto the Vse of the Instrvment called the Circles of Proportion. . . . . London, ${ }^{6} 6_{33}$, this being followed by Oughtred's To the English Gentrie etc. In the British Museum there is a copy of another impression of the Circles of Proportion, dated I639, with the Addition vnto the Vse of the Instrument etc., bearing the original date, I633, and with the epistle, To the English Gentrie, etc., inserted immediately after Forster's dedication, instead of at the end of the volume.

2 The complete title of the English edition is as follows: Trigonometrie, or, The manner of calculating the Sides and Angles of Triangles, by the Mathematical Canon, demonstrated. By William Oughtred Etonens. And published by Richard Stokes Fellow of Kings Colledge in Cambridge, and Arthur Haughton Gentleman. London, Printed by $R$. and W. Leybourn, for Thomas Johnson at the Golden Key in St. Pauls Church-yard. M.DC.LVII. 
Hand." D Doubtless more accurate on this point is a letter of Richard Stokes who saw the book through the press:

I have procured your Trigonometry to be written over in a fair hand, which when finished I will send to you, to know if it be according to your mind; for I intend (since you were pleased to give your assent) to endeavour to print it with Mr. Briggs his Tables, and so soon as I can get the Prutenic Tables I will turn those of the sun and moon, and send them to you. ${ }^{2}$

In the preface to the Latin edition Stokes writes:

Since this trigonometry was written for private use without the intention of having it published, it pleased the Reverend Author, before allowing it to go to press, to expunge some things, to change other things and even to make some additions and insert more lucid methods of exposition.

This much is certain, the Trigonometry bears the impress characteristic of Oughtred. Like all his mathematical writings, the book was very condensed. Aside from the tables, the text covered only 36 pages. Plane and spherical triangles were taken up together. The treatise is known in the history of trigonometry as among the very earliest works to adopt a condensed symbolism so that equations involving trigonometric functions could be easily taken in by the eye. In the work of 1657 , contractions are given as follows: $s=$ sine, $t=$ tangent, $s e=$ secant, $s c o=$ cosine (sine complement), $t c o=$ cotangent, se co $=$ cosecant, $\log =\operatorname{logarithm}, Z \mathrm{cru}=$ sum of the sides of a rectangle or right angle, $X \mathrm{cru}=$ difference of these sides. It has been generally overlooked by historians that Oughtred used the abbreviations of trigonometric functions, named above, a quarter of a century earlier,

${ }^{2}$ Jer. Collier, The Great Hislorical, Geographical, Genealogical and Poetical Dictionary, Vol. II, London, I 701, art. "Oughtred."

${ }^{2}$ Rigaud op. cil., Vol. I, p. 82. 
in his Circles of Proportion, I632, I633. Moreover, he used sometimes also the abbreviations which are current at the present time, namely $\sin =$ sine, $\tan =$ tangent, $\sec =$ secant. We know that the Circles of Proportion existed in manuscript many years before they were published. The symbol sv for sinus versus occurs in the Clavis of $163 \mathrm{I}$. The great importance of well-chosen symbols needs no emphasis to readers of the present day. With reference to Oughtred's trigonometric symbols. Augustus De Morgan said:

This is so very important a step, simple as it is, that Euler is justly held to have greatly advanced trigonometry by its introduction. Nobody that we know of has noticed that Oughtred was master of the improvement, and willing to have taught it, if people would have learnt. ${ }^{x}$

We find, however, that even Oughtred cannot be given the whole credit in this matter. By or before $\mathrm{I} 63 \mathrm{I}$ several other writers used abbreviations of the trigonometric functions. As early as 1624 the contractions sin for sine and tan for tangent appear on the drawing representing Gunter's scale, but Gunter did not use them in his books, except in the drawing of his scale. ${ }^{2}$ A closer competitor for the honor of first using these trigonometric abbreviations is Richard Norwood in his Trigonometrie, London, I63I, where $s$ stands for sine, $t$ for tangent, sc for sine complement (cosine), tc for tangent complement (cotangent), and $\mathrm{sec}$ for secant. Norwood was a teacher of mathematics in London and a well-known writer of books on navigation. Aside from the abbreviations just

${ }^{2}$ A. De Morgan, Budget of Paradoxes, London, 1872, p. 451; 2d ed., Chicago, 1915, Vol. II, p. 303.

${ }^{2}$ E. Gunter, Description and Use of the Sector, the Crosse-staffe and other Instruments, London, 1624, second book, p. 31. 
cited Norwood did not use nearly as much symbolism in his mathematics as did Oughtred.

Mention should be made of trigonometric symbols used even earlier than any of the preceding, in "An Appendix to the Logarithmes, shewing the practise of the Calculation of Triangles, etc.," printed in Edward Wright's edition of Napier's A Description of the Admirable Table of Logarithmes, London, I6I8. We referred to this "Appendix" in tracing the origin of the sign $X$. It contains, on p. 4 , the following passage: "For the Logarithme of an arch or an angle I set before $(s)$, for the antilogarithme or compliment thereof $\left(s^{*}\right)$ and for the Differential $(t) . "$ In further explanation of this rather unsatisfactory passage, the author (Oughtred ?) says, "As for example: $s B+B C=$ $C A$. that is, the Logarithme of an angle $B$. at the Base of a plane right-angled triangle, increased by the addition of the Logarithm of $B C$, the hypothenuse thereof, is equall to the Logarithme of $C A$ the cathetus."

Here "logarithme of an angle $B$ " evidently means " $\log \sin B$," just as with Napier, "Logarithms of the arcs" signifies really "Logarithms of the sines of the angles." In Napier's table, the numbers in the column marked "Differentiae" signify log sine minus log cosine of an angle; that is, the logarithms of the tangents. This explains the contraction $(t)$ in the "Appendix." The conclusion of all this is that as early as I6I8 the signs $s, s^{*}$, were used for sine, cosine, and tangent, respectively.

John Speidell, in his Breefe Treatise of Sphaericall Triangles, London, ${ }_{1627}$, uses Si. for sine, T. and Tan for tangent, Se. for secant, Si.Co. for cosine, Se. Co. for cosecant, T. Co. for cotangent.

The innovation of designating the sides and angles of a triangle by $A, B, C$, and $a, b, c$, so that $A$ was opposite 
$a, B$ opposite $b$, and $C$ opposite $c$, is attributed to Leonard Euler ( 1753 ), but was first used by Richard Rawlinson of Queen's College, Oxford, sometimes after I655 and before I668. Oughtred did not use Rawlinson's notation. ${ }^{\mathrm{I}}$

In trigonometry English writers of the first half of the seventeenth century used contractions more freely than their continental contemporaries; even more freely, indeed, than English writers of a later period. Von Braunmühl, the great historian of trigonometry, gives Oughtred much praise for his trigonometry, and points out that half a century later the army of writers on trigonometry had hardly yet reached the standard set by Oughtred's analysis. $^{2}$ Oughtred must be credited also with the first complete proof that was given to the first two of "Napier's analogies." His trigonometry contains seven-place tables of sines, tangents, and secants, and six-place tables of logarithmic sines and tangents; also seven-place logarithmic tables of numbers. At the time of Oughtred there was some agitation in favor of a wider introduction of decimal systems. This movement is reflected in those tables which contain the centesimal division of the degree, a practice which is urged for general adoption in our own day, particularly by the French.

\section{SOLUTION OF NUMERICAL EQUATIONS}

In the solution of numerical equations Oughtred does not mention the sources from which he drew, but the method is substantially that of the great French algebraist Vieta, as explained in a publication which appeared

I F. Cajori, "On the History of a Notation in Trigonometry," Nature, Vol. XCIV, I915, pp. 642, 643.

${ }^{2}$ A. von Braunmühl, Geschichte der Trigonometrie, 2. Teil, Leipzig, I9०3, pp. 42, 9 r. 
in 1600 in Paris under the title, De numerosa potestatum purarum atque adfectarum ad exegesin resolutione tractatus. In view of the fact that Vieta's process has been described inaccurately by leading modern historians including $\mathrm{H}$. Hankel $^{\mathrm{x}}$ and $\mathrm{M}$. Cantor, ${ }^{2}$ it may be worth while to go into some detail.3 By them it is made to appear as identical with the procedure given later by Newton. The two are not the same. The difference lies in the divisor used. What is now called "Newton's method" is Newton's method as modified by Joseph Raphson. ${ }^{4}$ The NewtonRaphson method of approximation to the roots of an equation $f(x)=0$ is usually given the form $a-\left[f(a) / f^{\prime}(a)\right]$, where $a$ is an approximate value of the required root. It will be seen that the divisor is $f^{\prime}(a)$. Vieta's divisor is different; it is

$$
\left|f\left(a+s_{\mathrm{I}}\right)-f(a)\right|-s_{\mathrm{I}}^{n},
$$

where $f(x)$ is the left of the equation $f(x)=k, n$ is the degree of equation, and $s_{\mathbf{I}}$ is a unit of the denomination of the digit next to be found. Thus in $x^{3}+420000 x=24765$ I 7 I 3 , it can be shown that 4I 7 is approximately a root; suppose that $a$ has been taken to be 400 , then $s_{\mathrm{I}}=\mathrm{IO}$; but if, at the next step of approximation, $a$ is taken to be $4 \mathrm{IO}$, then $s_{\mathrm{I}}=\mathrm{I}$. In this example, taking $a=400$, Vieta's divisor

${ }^{x} \mathrm{H}$. Hankel, Geschichte der Mathematik in Alterthum und Mittelalter, Leipzig, 1874, pp. 369, 370.

${ }^{2}$ M. Cantor, Vorlesungen über Geschichte der Mathematik, II, I900, pp. 640, 641.

${ }^{3}$ This matter has been discussed in a paper by F. Cajori, "A History of the Arithmetical Methods of Approximation, etc., Colorado College Publication, General Series No. 5I, 1910, pp. 182-84. Later this subject was again treated by G. Eneström in Bibliotheca mathematica, 3. Folge, Vol. XI, 191I, pp. 234, 235.

${ }^{4}$ See F. Cajori, op. cil., p. 193. 
would have been 91 20000; Newton's divisor would have been 900000 .

A comparison of Vieta's method with the NewtonRaphson method reveals the fact that Vieta's divisor is more reliable, but labors under the very great disadvantage of requiring a much larger amount of computation. The latter divisor is accurate enough and easier to compute. Altogether the Newton-Raphson process marks a decided advance over that of Vieta.

As already stated, it is the method of Vieta that Oughtred explains. The Englishman's exposition is an improvement on that of Vieta, printed forty years earlier. Nevertheless, Oughtred's explanation is far from easy to follow. The theory of equations was at that time still in its primitive stage of development. Algebraic notation was not sufficiently developed to enable the argument to be condensed into a form easily surveyed. So complicated does Vieta's process of approximation appear that M. Cantor failed to recognize that Vieta possessed a uniform mode of procedure. But when one has in mind the general expression for Vieta's divisor which we gave above, one will recognize that there was marked uniformity in Vieta's approximations.

Oughtred allows himself twenty-eight sections in which to explain the process and at the close cannot forbear remarking that 28 is a "perfect" number (being equal to the sum of its divisors, I, 2, 4, 7, I4).

The early part of his exposition shows how an equation may be transformed so as to make its roots Io, I00, I000, or ${ }_{1}{ }^{\mathrm{m}}$ times smaller. This simplifies the task of "locating a root"; that is, of finding between what integers the root lies.

Taking one of Oughtred's equations, $x^{4}-72 x^{3}+238600 x$ $=8725^{8} 15$, upon dividing $72 x^{3}$ by 10, $238600 x$ by 1000, 
and $8725^{8} \mathrm{I}_{5}$ by 10,000 , we obtain $x^{4}-7 \cdot 2 x^{3}+238 \cdot 6 x=$ $872 \cdot 5$. Dividing both sides by $x$, we obtain $x^{3}+238 \cdot 6-$ $\left.7 \cdot 2 x^{2}=x\right) 872 \cdot 5$. Letting $x=4$, we have $64+238 \cdot 6-$ I I $5 \cdot 2=\mathrm{I} 87 \cdot 4$.

But 4$) 872 \cdot 5(2 \mathrm{I} 8 \cdot \mathrm{I} ; 4$ is too small. Next let $x=5$, we have $125+238 \cdot 6-\mathrm{I} 80=\mathrm{I} 83 \cdot 6$.

But 5$) 872 \cdot 5(174 \cdot 5 ; 5$ is too large. We take the lesser value, $x=4$, or in the original equation, $x=40$. This method may be used to find the second digit in the root. Oughtred divides both sides of the equation by $x^{2}$, and obtains $\left.\left.x^{2}+x\right) 238600-72 x=x^{2}\right) 87258$ I 5 . He tries $x=47$ and $x=48$, and finds that $x=47$.

He explains also how the last computation may be done by logarithms. Thereby he established for himself the record of being the first to use logarithms in the solution of affected equations.

As an illustration of Oughtred's method of approximation after the root sought has been located, we have chosen for brevity a cubic in preference to a quartic. We selected the equation $x^{3}+420000 x=24765$ I 7 I3. By the process explained above a root is found to lie between $x=400$ and $x=500$. From this point on, the approximation as given by Oughtred is as shown on p. 43 .

In further explanation of this process, observe that the given equation is of the form $L_{c}+C_{q} L=D_{c}$, where $L_{c}$ is our $x, C_{q}=420000, D_{c}=24765{ }^{17}$ I3. In the first step of approximation, let $L=A+E$, where $A=400$ and $E$ is, as yet, undetermined. We have

$$
L_{c}=(A+E)^{3}=A^{3}+3 A^{2} E+3 A E^{2}+E^{3}
$$

and

$$
C_{q} L=420000(A+E) .
$$

Subtract from $247^{6} 5^{\text {I }}$ I 3 the sum of the known terms $A^{3}$ 
"Exemplum II

$$
\mathrm{I} c+420000 \mathrm{l}=24 \dot{7} 65 \dot{\mathrm{I}} \mathrm{7} \mathrm{\textrm {I }} \dot{3}
$$

Hoc est, $L_{c}+C_{q} L=D_{c}$

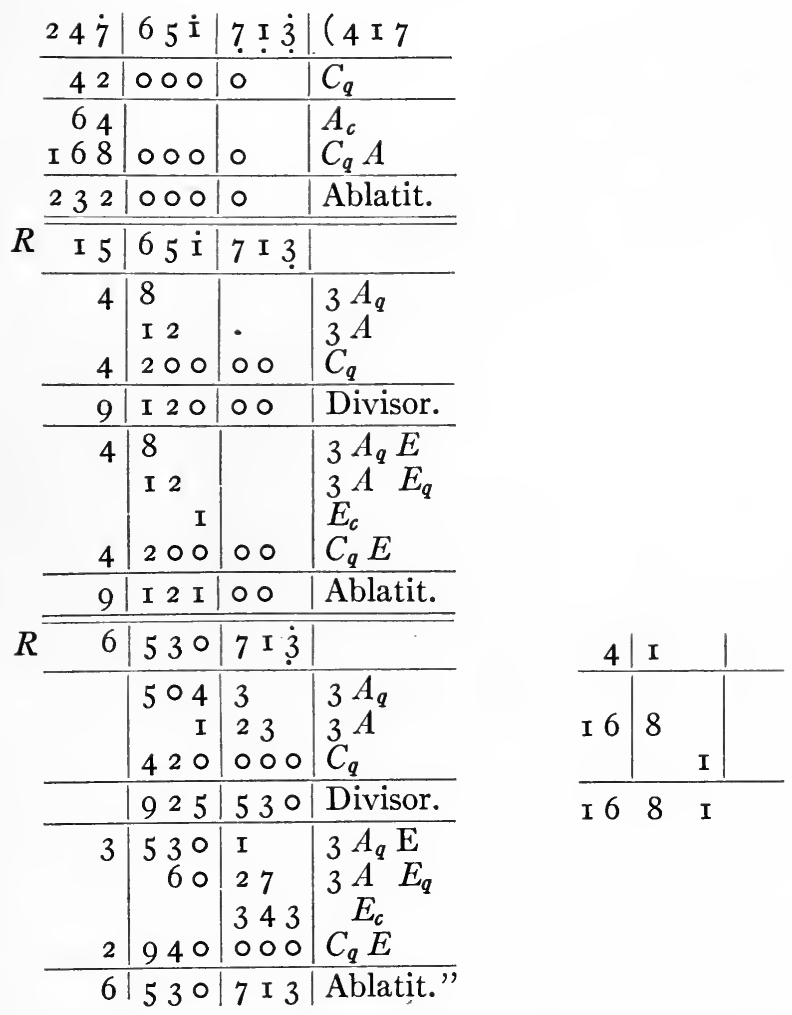

(his $A_{c}$ ) and $420000 A$ (his $C_{q} A$ ). This sum is 232000000 the remainder is $\mathrm{I}_{5}{ }^{6} \mathrm{I}^{\mathrm{I}} \mathrm{I} 3 \mathrm{~s}$. 
Next, he evaluates the coefficients of $E$ in $3 A^{2} E$ and $420000 E$, also $3 A$, the coefficient of $E^{2}$. He obtains $3 A^{2}=480000,3 A=\mathrm{r} 200, C_{q}=420000$. He interprets $3 A^{2}$ and $C_{q}$ as tens, $3 A$ as hundreds. Accordingly, he obtains as their sum 9120000, which is the divisor for finding the second digit in the approximation. Observe that this divisor is the value of $\left|f\left(a+s_{\mathrm{I}}\right)-f(a)\right|-s_{\mathrm{I}}{ }^{n}$ in our general expression, where $a=400, s_{\mathrm{x}}=\mathrm{I} \circ, n=3, f(x)=$ $x^{3}+420000 x$.

Dividing the remainder $\mathrm{I}_{5}^{6} 5_{5} \mathrm{I} 7 \mathrm{I} 3$ by $9 \mathrm{r} 20000$, he obtains the integer I in ten's place; thus $E=10$, approximately. He now computes the terms $3 A^{2} E, 3 A E^{2}$ and $E^{3}$ to be, respectively, 4800000 , I 20000 , 1000. Their sum is 9121000 . Subtracting it from the previous remainder, $\mathrm{I}_{56} 6 \mathrm{I}^{\mathrm{I}} \mathrm{I}$, leaves the new remainder, $65307 \mathrm{I} 3$.

From here on each step is a repetition of the preceding step. The new $A$ is $4 \mathrm{ro}$, the new $E$ is to be determined. We have now in closer approximation, $L=A+E$. This time we do not subtract $A^{3}$ and $\mathrm{C}_{q} A$, because this subtraction is already affected by the preceding work.

We find the second trial divisor by computing the sum of $3 A^{2}, 3 A$ and $C_{q}$; that is, the sum of $504300, \mathrm{r} 230$, 420000, which is 925530. Again, this divisor can be computed by our general expression for divisors, by taking $a=4 \mathrm{IO}, s_{\mathrm{I}}=\mathrm{I}, n=3$.

Dividing $65307 \mathrm{I} 3$ by 925530 yields the integer 7 . Thus $E=7$. Computing $3 A^{2} E, 3 A E^{2}, E^{3}$ and subtracting their sum, the remainder is 0 . Hence $4 \mathrm{I} 7$ is an exact root of the given equation.

Since the extraction of a cube root is merely the solution of a pure cubic equation, $x^{3}=n$, the process given above may be utilized in finding cube roots. This is 
precisely what Oughtred does in chap. xiv of his Clavis. If the foregoing computation is modified by putting $C_{q}=0$, the process will yield the approximate cube root of 24765 I 7 I3.

Oughtred solves 16 examples by the process of approximation here explained. Of these, 9 are cubics, 5 are quartics, and 2 are quintics. In all cases he finds only one or two real roots. Of the roots sought, five are irrational, the remaining are rational and are computed to their exact values. Three of the computed roots have 2 figures each, 9 roots have 3 figures each, 4 roots have 4 figures each. While no attempt is made to secure all the roots-methods of computing complex roots were invented much later-he computes roots of equations which involve large coefficients and some of them are of a degree as high as the fifth. In view of the fact that many editions of the Clavis were issued, one impression as late as 1702 , it contributed probably more than any other book to the popularization of Vieta's method in England.

Before Oughtred, Thomas Harriot and William Milbourn are the only Englishmen known to have solved numerical equations of higher degrees. Milbourn published nothing. Harriot slightly modified Vieta's process by simplifying somewhat the formation of the trial divisor. This method of approximation was the best in existence in Europe until the publication by Wallis in 1685 of Newton's method of approximation.

It should be stated that, before the time of Newton, the best method of approximation to the roots of numerical equations existed, not in Europe, but in China. As early as the thirteenth century the Chinese possessed a method which is almost identical with what is known today as "Horner's method." 


\section{LOGARITHMS}

Oughtred's treatment of logarithms is quite in accordance with the more recent practice. ${ }^{x}$ He explains the finding of the "index" (our "characteristic"); he states that "the sum of two Logarithms is the Logarithm of the Product of their Valors; and their difference is the Logarithm of the Quotient," that "the Logarithm of the side [436] drawn upon the Index number [2] of dimensions of any Potestas is the logarithm of the same Potestas" $\left[43^{2}\right]$, that "the logarithm of any Potestas $\left[43^{2}\right]$ divided by the number of its dimensions [2] affordeth the Logarithm of its Root [436]." These statements of Oughtred occur for the first time in the Key of the Mathematicks of I647; the Clavis of $\mathrm{I}_{3} \mathrm{I}$ contains no treatment of logarithms.

If the characteristic of a logarithm is negative, Oughtred indicates this fact by placing the - above the characteristic. He separates the characteristic and mantissa by a comma, but still uses the sign $L$ to indicate decimal fractions. He uses the contraction "log."

\section{INVENTION OF THE SLIDE RULE; CONTROVERSY ON PRIORITY OF INVENTION}

Oughtred's most original line of scientific activity is the one least known to the present generation. Augustus De Morgan, in speaking of Oughtred, who was sometimes called "Oughtred Aetonensis," remarks: "He is an animal of extinct race, an Eton mathematician. Few Eton men, even of the minority which knows what a sliding rule is, are aware that the inventor was of their

${ }^{x}$ See William Oughtred's Key of the Mathemalicks, London, I694, pp. 173-75, tract, "Of the Resolution of the Affected Equations," or any edition of the Clavis after the first. 
own school and college." I The invention of the slide rule has, until recently, ${ }^{2}$ been a matter of dispute; it has been erroneously ascribed to Edmund Gunter, Edmund Wingate, Seth Partridge, and others. We have been able to establish that William Oughtred was the first inventor of slide rules, though not the first to publish thereon. We shall see that Oughtred invented slide rules about 1622 , but the descriptions of his instruments were not put into print before $\mathrm{I}_{3} 2$ and $\mathrm{I}_{633}$. Meanwhile one of his own pupils, Richard Delamain, who probably invented the circular slide rule independently, published a description in I630, at London, in a pamphlet of 32 pages entitled Grammelogia; or the Mathematicall Ring. In editions of this pamphlet which appeared during the following three or four years, various parts were added on, and some parts of the first and second editions eliminated. Thus Delamain antedates Oughtred two years in the publication of a description of a circular slide rule. But Oughtred had invented also a rectilinear slide rule, a description of which appeared in 1633 . To the invention of this Oughtred has a clear title. A bitter controversy sprang up between Delamain on one hand, and Oughtred and some of his pupils on the other, on the priority and independence of invention of the circular slide rule. Few inventors and scientific men are so fortunate as to escape contests. The reader needs only to recall the disputes which have arisen, involving the researches of Sir Isaac Newton and Leibniz on the differential and integral calculus, of Thomas Harriot and René Descartes relating to the theory of equations, of Robert Mayer,

I A. De Morgan, op. cit., p. 45r; 2d ed., Vol. II, p. 303.

${ }^{2}$ See F. Cajori, History of the Logarithmic Slide Rule, New York, 1909, pp. 7-14, Addenda, p. ii. 
Hermann von Helmholtz, and Joule on the principle of the conservation of energy, or of Robert Morse, Joseph Henry, Gauss and Weber, and others on the telegraph, to see that questions of priority and independence are not uncommon. The controversy between Oughtred and Delamain embittered Oughtred's life for many years. He refers to it in print on more than one occasion. We shall confine ourselves at present to the statement that it is by no means clear that Delamain stole the invention from Oughtred; Delamain was probably an independent inventor. Moreover, it is highly probable that the controversy would never have arisen, had not some of Oughtred's pupils urged and forced him into it. William Forster stated in the preface to the Circles of Proportion of $\mathrm{I}_{3}{ }_{32}$ that while he had been carefully preparing the manuscript for the press, "another to whom the Author [Oughtred] in a louing confidence discouered this intent, using more hast then good speed, went about to preocupate." It was this passage which started the conflagration. Another pupil, W. Robinson, wrote to Oughtred, when the latter was preparing his Apologeticall Epistle as a reply to Delamain's countercharges: "Good sir, let me be beholden to you for your Apology whensoever it comes forth, and (if I speak not too late) let me entreat you, whip ignorance well on the blind side, and we may turn him round, and see what part of him is free."I As stated previously, Oughtred's circular slide rule was described by him in his Circles of Proportion, London, 1632, which was translated from Oughtred's Latin manuscript and then seen through the press by his pupil, William Forster. In I6 33 appeared An Addition vnto the Vse of the Instrvment called the Circles

${ }^{2}$ Rigaud, op. cil., Vol. I, p. I 2. 
of Proportion which contained at the end "The Declaration of the two Rulers for Calculation," giving a description of Oughtred's rectilinear slide rule. This Addition was bound with the Circles of Proportion as one volume. About the same time Oughtred described a modified form of the rectilinear slide rule, to be used in London for gauging. ${ }^{x}$

I The New Artificial Gauging Line or Rod: together with rules concerning the use thereof: Invented and written by William Oughtred, London, 1633 . 


\section{CHAPTER III}

\section{MINOR WORKS}

Among the minor works of Oughtred must be ranked his booklet of forty pages to which reference has already been made, entitled, The New Artificial Gauging Line or Rod, London, I633. His different designs of slide rules and his inventions of sun-dials as well as his exposition of the making of watches show that he displayed unusual interest and talent in the various mathematical instruments. A short tract on watchmaking was brought out in London as an appendix to the Horological Dialogues of a clock- and watchmaker who signed himself "J. S." (John Smith?). Oughtred's tract appeared with its own title-page, but with pagination continued from the preceding part, as $A n$ Appendix wherein is contained a Method of Calculating all Numbers for Watches. Written originally by that famous Mathematician Mr. William Oughtred, and now made Publick. By J. S. of London, Clock-maker. London, 1675 .

"J. S." says in his preface:

The method following was many years since Compiled by Mr. Oughtred for the use of some Ingenious Gentlemen his friends, who for recreation at the University, studied to find out the reason and Knowledge of Watch-work, which seemed also to be a thing with which Mr. Oughtred himself was much affected, as may in part appear by his putting out of his own Son to the same Trade, for whose use (as I am informed) he did compile a larger tract, but what became of it cannot be known. 
Notwithstanding Oughtred's marked activity in the design of mathematical instruments, and his use of surveying instruments, he always spoke in deprecating terms of their importance and their educational value. In his epistle against Delamain he says:

The Instruments I doe not value or weigh one single penny. If $I$ had been ambitious of praise, or had thought them (or better then they) worthy, at which to have taken my rise, out of my secure and quiet obscuritie, to mount up into glory, and the knowledge of men: I could have done it many yeares before. . . . .

Long agoe, when I was a young student of the Mathematicall Sciences, I tryed many wayes and devices to fit my selve with some good Diall or Instrument portable for my pocket, to finde the houre, and try other conclusions by, and accordingly framed for that my purpose both Quadrants, and Rings, and Cylinders, and many other composures. Yet not to my full content and satisfaction; for either they performed but little, or els were patched up with a diversity of lines by an unnaturall and forced contexture. At last I . . . found what I had before with much studie and paines in vaine sought for. ${ }^{\mathrm{I}}$

Mention has been made in the previous pages of two of his papers on sun-dials, prepared (as he says) when he was in his twenty-third year. The first was published in the Clavis of 1647 . The second paper appeared in his Circles of Proportion.

Both before and after the time of Oughtred much was written on sun-dials. Such instruments were set up against the walls of prominent buildings, much as the faces of clocks in our time. The inscriptions that were put upon sun-dials are often very clever: "I count only the hours of sunshine," "Alas, how fleeting." A sun-dial

${ }^{\simeq}$ W. Oughtred, A pologeticall Epistle, p. 13. 
on the grounds of Merchiston Castle, in Edinburgh, where the inventor of logarithms, John Napier, lived for many years, bears the inscription, "Ere time be tint, tak tent of time" (Ere time be lost, take heed of time).

Portable sun-dials were sometimes carried in pockets, as we carry watches. Thus Shakespeare,.in As You Like It, Act II, sc. vii:

"And then he drew a diall from his poke."

Watches were first made for carrying in the pocket about 1658 .

Because of this literary, scientific, and practical interest in methods of indicating time it is not surprising that Oughtred devoted himself to the mastery and the advancement of methods of time-measurement.

Besides the accounts previously noted, there came from his pen: The Description and Use of the double Horizontall Dyall: Whereby not onely the hower of the day is sherwe; but also the Meridian Line is found: And most Astronomical Questions, which may be done by the Globe, are resolved. Invented and written by $W$. O., London, I636.

The "Horizontall Dyall" and "Horologicall Ring" appeared again as appendixes to Oughtred's translation from the French of a book on mathematical recreations.

The fourth French edition of that work appeared in I627 at Paris, under the title of Recreations mathematiqve, written by "Henry van Etten," a pseudonym for the French Jesuit Jean Leurechon (1591-1690). English editions appeared in 1633,1653 , and 1674 . The full title of the ${ }^{6} 653$ edition conveys an idea of the contents of the text: Mathematical Recreations, or, A Collection of many Problemes, extracted out of the Ancient and Modern Philos- 
ophers, as Secrets and Experiments in Arithmetick, Geometry, Cosmographie, Horologiographie, Astronomie, Navigation, Musick, Opticks, Architecture, Statick, Mechanicks, Chemistry, Water-works, Fire-works, ${ }^{\circ} \mathrm{c}$. Not vulgarly manifest till now. Written first in Greek and Latin, lately compil'd in French, by Henry Van Etten, . and now in English, with the Examinations and Augmentations of divers Modern Mathematicians. Whereunto is added the Description and Use of the Generall Horologicall Ring. And The Double Horizontall Diall. Invented and written by William Oughtred. London, Printed for William Leake, at the Signe of the Crown in Fleet-street, between the two Temple-Gates. MDCLIII.

The graphic solution of spherical triangles by the accurate drawing of the triangles on a sphere and the measurement of the unknown parts in the drawing was explained by Oughtred in a short tract which was published by his son-in-law, Christopher Brookes, under the following title: The Solution of all Sphaerical Triangles both right and oblique By the Planisphaere: Whereby two of the Sphaerical partes sought, are at one position most easily found out. Published with consent of the Author, By Christopher Brookes, Mathematique Instrument-maker, and Manciple of Wadham Colledge, in Oxford.

Brookes says in the preface:

I have oftentimes seen my Reverend friend Mr. W. O. in his resolution of all sphaericall triangles both right and oblique, to use a planisphaere, without the tedious labour of Trigonometry by the ordinary Canons: - which planisphaere he had delineated with his own hands, and used in his calculations more than Forty years before.

Interesting as one of our sources from which Oughtred obtained his knowledge of the conic sections is his study 
of Mydorge. A tract which he wrote thereon was published by Jonas Moore, in his Arithmetick in two books .... [containing also] the two first books of Mydorgius his conical sections analyzed by that reverend devine $M r . W$. Oughtred, Englished and completed with cuts. London, 1660. Another edition bears the date I688.

To be noted among the minor works of Oughtred are his posthumous papers. He left a considerable number of mathematical papers which his friend Sir Charles Scarborough had revised under his direction and published at Oxford in 1676 in one volume under the title, Gulielmi Oughtredi, Etonensis, quondam Collegii Regalis in Cantabrigia Socii, Opuscula Mathematica hactenus inedita. Its nine tracts are of little interest to a modern reader.

Here we wish to give our reasons for our belief that Oughtred is the author of an anonymous tract on the use of logarithms and on a method of logarithmic interpolation which, as previously noted, appeared as an "Appendix" to Edward Wright's translation into English of John Napier's Descriptio, under the title, A Description of the Admirable Table of Logarithmes, London, 1618. The "Appendix" bears the title, "An Appendix to the Logarithmes, showing the practise of the Calculation of Triangles, and also a new and ready way for the exact finding out of such lines and Logarithmes as are not precisely to be found in the Canons." It is an able tract. A natural guess is that the editor of the book, Samuel Wright, a son of Edward Wright, composed this "Appendix." More probable is the conjecture which (Dr. J. W. L. Glaisher informs me) was made by Augustus De Morgan, attributing the authorship to Oughtred. Two reasons in support of this are advanced by Dr. Glaisher, the use of $x$ in the "Appendix" as the sign of multiplication (to 
Oughtred is generally attributed the introduction of the cross $X$ for multiplication in $\mathrm{r} 63 \mathrm{r}$ ), and the then unusual designation "cathetus" for the vertical leg of a right triangle, a term appearing in Oughtred's books. We are able to advance a third argument, namely, the occurrence in the "Appendix" of $\left(S^{*}\right)$ as the notation for sine complement (cosine), while Seth Ward, an early pupil of Oughtred, in his Idea trigonometriae demonstratae, Oxford, r6 54 , used a similar notation $\left(S^{\prime}\right)$. It has been stated elsewhere that Oughtred claimed Seth Ward's exposition of trigonometry as virtually his own. Attention should be called also to the fact that, in his Trigonometria, p. 2, Oughtred uses (') to designate $180^{\circ}$-angle.

Dr. J. W. L. Glaisher is the first to call attention to other points of interest in this "Appendix." The interpolations are effected with the aid of a small table containing the logarithms of 72 sines. Except for the omission of the decimal point, these logarithms are natural logarithms - the first of their kind ever published. In this table we find $\log 10=2302584$; in modern notation, this is stated, $\log _{e} 10=2.302584$. The first more extended table of natural logarithms of numbers was published by John Speidell in the 1622 impression of his New Logarithmes, which contains, besides trigonometric tables, the logarithms of the numbers I-I000.

The "Appendix" contains also the first account of a method of computing logarithms, called the "radix method," which is usually attributed to Briggs who applied it in his Arithmetica logarithmica, I624. In general, this method consists in multiplying or dividing a number, whose logarithm is sought, by a suitable factor and resolving the result into factors of the form $\mathrm{I} \pm \frac{x}{10^{n}}$. 
The logarithm of the number is then obtained by adding the previously calculated logarithms of the factors. The method has been repeatedly rediscovered, by Flower in I77 I, Atwood in I786, Leonelli in I802, Manning in I806, Weddle in 1845 , Hearn in 1847 , and Orchard in 1848 .

We conclude with the words of Dr. J. W. L. Glaisher:

The Appendix was an interesting and remarkable contribution to mathematics, for in its sixteen small pages it contains (I) the first use of the sign $\times$; (2) the first abbreviations, or symbols, for the sine, tangent, cosine, and cotangent; (3) the invention of the radix method of calculating logarithms; (4) the first table of hyperbolic logarithms. ${ }^{x}$

"Quarterly Journal of Pure and Applied Mathematics, Vol. XLVI, (1915), p. I69. In this article Glaisher republishes the "Appendix" in full. 


\section{CHAPTER IV}

OUGHTRED'S INFLUENCE UPON MATHEMATICAL
PROGRESS AND TEACHING

OUGHTRED AND HARRIOT

Oughtred's Clavis mathematicae was the most influential mathematical publication in Great Britain which appeared in the interval between John Napier's Mirifici logarithmorum canonis descriptio, Edinburgh, $\mathrm{I} 6 \mathrm{I} 4$, and the time, forty years later, when John Wallis began to publish his important researches at Oxford. The year r63 I is of interest as the date of publication, not only of Oughtred's Clavis, but also of Thomas Harriot's Artis analyticae praxis. We have no evidence that these two mathematicians ever met. Through their writings they did not influence each other. Harriot died ten years before the appearance of his magnum opus, or ten years before the publication of Oughtred's Clavis. Strangely, Oughtred, who survived Harriot thirty-nine years, never mentions him. There is no doubt that, of the two, Harriot was the more original mind, more capable of penetrating into new fields of research. But he had the misfortune of having a strong competitor in René Descartes in the development of algebra, so that no single algebraic achievement stands out strongly and conspicuously as Harriot's own contribution to algebraic science. As a text to serve as an introduction to algebra, Harriot's Artis analyticae praxis was inferior to Oughtred's Clavis. The former was a much larger book, not as conveniently portable, compiled after the author's death by others, 
and not prepared with the care in the development of the details, nor with the coherence and unity and the profound pedagogic insight which distinguish the work of Oughtred. Nor was Harriot's position in life such as to be surrounded by so wide a circle of pupils as was Oughtred. To be sure, Harriot had such followers as Torporley, William Lower, and Protheroe in Wales, but this group is small as compared with Oughtred's.

\section{OUGHTRED'S PUPILS}

There was a large number of distinguished men who, in their youth, either visited Oughtred's home and studied under his roof or else read his Clavis and sought his assistance by correspondence. We permit Aubrey to enumerate some of these pupils in his own gossipy style:

Seth Ward, M.A., a fellow of Sydney Colledge in Cambridge (now bishop of Sarum), came to him, and lived with him halfe a yeare (and he would not take a farthing for his diet), and learned all his mathematiques of him. Sir Jonas More was with him a good while, and learn't; he was but an ordinary logist before. Sir Charles Scarborough was his scholar; so Dr. John Wallis was his scholar; so was Christopher Wren his scholar, so was Mr. .... Smethwyck, Regiae Societatis Socius. One Mr. Austin (a most ingeniose man) was his scholar, and studyed so much that he became mad, fell a laughing, and so dyed, to the great griefe of the old gentleman. Mr. ..... Stokes, another scholar, fell mad, and dream't that the good old gentleman came to him, and gave him good advice, and so he recovered, and is still well. Mr. Thomas Henshawe, Regiae Societatis Socius, was his scholar (then a young gentleman). But he did not so much like any as those that tugged and tooke paines to worke out questions. He taught all free. 
He could not endure to see a scholar write an ill hand; he taught them all presently to mend their hands. ${ }^{\mathrm{x}}$

Had Oughtred been the means of guiding the mathematical studies of only John Wallis and Christopher Wren-one the greatest English mathematician between Napier and Newton, the other one of the greatest architects of England-he would have earned profound gratitude. But the foregoing list embraces nine men, most of them distinguished in their day. And yet Aubrey's list is very incomplete. It is easy to more than double it by adding the names of William Forster, who translated from Latin into English Oughtred's Circles of Proportion; Arthur Haughton, who brought out the I660 Oxford edition of the Circles of Proportion; Robert Wood, an educator and politician, who assisted Oughtred in the translation of the Clavis from Latin into English for the edition of 1647; W. Gascoigne, a man of promise, who fell in I644 at Marston Moor; John Twysden, who was active as a publisher; William Sudell, N. Ewart, Richard Shuttleworth, William Robinson, and William Howard, the son of the Earl of Arundel, for whose instruction Oughtred originally prepared the manuscript treatise that was published in $\mathrm{I} 63 \mathrm{I}$ as the Clavis mathematicae.

Nor must we overlook the names of Lawrence Rooke (who "did admirably well read in Gresham Coll. on the sixth chapt. of the said book," the Clavis); Christopher Brookes (a maker of mathematical instruments who married a daughter of the famous mathematician); William Leech and William Brearly (who with Robert Wood "have been ready and helpfull incouragers of me [Oughtred] in this labour" of preparing the English Clavis

I Aubrey, op. cit., Vol. II, I898, p. Ic8. 
of 1647), and Thomas Wharton, who studied the Clavis and assisted in the editing of the edition of 1647 .

The devotion of these pupils offers eloquent testimony, not only of Oughtred's ability as a mathematician, but also of his power of drawing young men to him-of his personal magnetism. Nor should we omit from the list Richard Delamain, a teacher of mathematics in London, who unfortunately had a bitter controversy with Oughtred on the priority and independence of the invention of the circular slide rule and a form of sun-dial. Delamain became later a tutor in mathematics to King Charles I, and perished in the civil war, before 1645 .

\section{OUGHTRED, THE "TODHUNTER OF THE SEVENTEENTH CENTURY"}

To afford a clearer view of Oughtred as a teacher and mathematical expositor we quote some passages from various writers and from his correspondence. Anthony Wood $^{x}$ gives an interesting account of how Seth Ward and Charles Scarborough went from Cambridge University to the obscure home of the country mathematician to be initiated into the mysteries of algebra:

Mr. Cha. Scarborough, then an ingenious young student and fellow of Caius Coll. in the same university, was his [Seth Ward's] great acquaintance, and both being equally students in that faculty and desirous to perfect themselves, they took a journey to Mr. Will. Oughtred living then at Albury in Surrey, to be informed in many things in his Clavis mathematica which seemed at that time very obscure to them. Mr. Oughtred treated them with great humanity, being very much pleased to see such ingenious young men apply themselves to these studies, and in short time he sent them away well satisfied in their desires. When they returned to Cambridge, they after-

'Wood's Athenae Oxonienses (ed. P. Bliss), Vol. IV, 1820, p. 247. 
wards read the Clav. Math. to their pupils, which was the first time that book was read in the said university. Mr. Laur. Rook, a disciple of Oughtred, I think, and Mr. Ward's friend, did admirably well read in Gresham Coll. on the sixth chap. of the said book, which obtained him great repute from some and greater from Mr. Ward, who ever after had an especial favour for him.

Anthony Wood makes a similar statement about Thomas Henshaw:

While he remained in that coll. [University College, Oxford] which was five years .... he made an excursion for about 9 months to the famous mathematician Will. Oughtred parson of Aldbury in Surrey, by whom he was initiated in the study of mathematics, and afterwards retiring to his coll. for a time, he at length went to London, was entered a student in the Middle Temple. ${ }^{\mathrm{x}}$

Extracts from letters of W. Gascoigne to Oughtred, of the years $\mathrm{r} 640$ and I64I, throw some light upon mathematical teaching of the time:

Amongst the mathematical rarities these times have afforded, there are none of that small number I (a late intruder into these studies) have yet viewed, which so fully demonstrates their authors' great abilities as your Clavis, not richer in augmentations, than valuable for contraction; . . . .

Your belief that there is in all inventions aliquid divinum, an infusion beyond human cogitations, I am confident will appear notably strengthened, if you please to afford this truth belief, that I entered upon these studies accidentally after I betook myself to the country, having never had so much aid as to be taught addition, nor the discourse of an artist (having left both Oxford and London before I knew what any proposition in geometry meant) to inform me what were the best authors. ${ }^{2}$

${ }^{x}$ Wood, op. cit., Vol. II, p. 445.

${ }^{2}$ Rigaud, op. cit., Vol. I, pp. 33; 35. 
The following extracts from two letters by W. Robinson, written before the appearance of the 1647 English edition of the Clavis, express the feeling of many readers of the Clavis on its extreme conciseness and brevity of explanation:

I shall long exceedingly till I see your Clavis turned into a pick-lock; and I beseech you enlarge it, and explain it what you can, for we shall not need to fear either tautology or superfluity; you are naturally concise, and your clear judgment makes you both methodical and pithy; and your analytical way is indeed the only way. . . . .

I will once again earnestly entreat you, that you be rather diffuse in the setting forth of your English mathematical Clavis, than concise, considering that the wisest of men noted of old, and said stultorum infinitus est numerus, these arts cannot be made too easy, they are so abstruse of themselves, and men either so lazy or dull, that their fastidious wits take a loathing at the very entrance of these studies, unless it be sweetened on with plainness and facility. Brevity may well argue a learned author, that without any excess or redundance, either of matter or words, can give the very substance and essence of the thing treated of; but it seldom makes a learned scholar; and if one be capable, twenty are not; and if the master sum up in brief the pith of his own long labours and travails, it is not easy to imagine that scholars can with less labour than it cost their masters dive into the depths thereof. ${ }^{x}$

Here is the judgment of another of Oughtred's friends: . . . . with the character I received from your and my noble friend Sir Charles Cavendish, then at Paris, of your second edition of the same piece, made me at my return into England speedily to get, and diligently peruse the same. Neither truly did I find my expectation deceived; having with admiration often considered how it was possible (even in the hardest

${ }^{x}$ Rigaud, op. cil., Vol. I, pp. I6, 26. 
things of geometry) to deliver so much matter in so few words, yet with such demonstrative clearness and perspicuity: and hath often put me in mind of learned Mersennus his judgment (since dead) of it, that there was more matter comprehended in that little book than in Diophantus, and all the ancients. . . . .

Oughtred's own feeling was against diffuseness in textbook writing. In his revisions of his Clavis the original character of that book was not altered. In his reply to W. Robinson, Oughtred said:

... But my art for all such mathematical inventions I have set down in my Clavis Mathematica, which therefore in my title I say is tum logisticae cum analyticae adeoque totius mathematicae quasi clavis, which if any one of a mathematical genius will carefully study, (and indeed it must be carefully studied,) he will not admire others, but himself do wonders. But I (such is my tenuity) have enough fungi vice cotis, acutum reddere quae ferrum valet, exsors ipsa secandi, or like the touchstone, which being but a stone, base and little worth, can shew the excellence and riches of gold. ${ }^{2}$

John Wallis held Oughtred's Clavis in high regard. When in correspondence with John Collins concerning plans for a new edition, Wallis wrote in 1666-67, six years after the death of Oughtred:

.... But for the goodness of the book in itself, it is that (I confess) which I look upon as a very good book, and which doth in as little room deliver as much of the fundamental and useful part of geometry (as well as of arithmetic and algebra) as any book I know; and why it should not be now acceptable I do not see. It is true, that as in other things so in mathematics, fashions will daily alter, and that which Mr. Oughtred designed by great letters may be now by others be designed by small; but a mathematician will, with the same ease and advantage, understand $A_{c}$, and $a^{3}$ or $a a a . \ldots$ And the like

${ }^{s}$ Rigaud, op. cit., Vol. I, p. 66.

${ }^{2}$ Ibid., Vol. I, p. 9. 
I judge of Mr. Oughtred's Clavis, which I look upon (as those pieces of Vieta who first went in that way) as lasting books and classic authors in this kind; to which, notwithstanding, every day may make new additions. ....

But I confess, as to my own judgment, I am not for making the book bigger, because it is contrary to the design of it, being intended for a manual or contract; whereas comments, by enlarging it, do rather destroy it. ... But it was by him intended, in a small epitome, to give the substance of what is by others delivered in larger volumes. .... $x^{x}$

That there continued to be a group of students and teachers who desired a fuller exposition than is given by Oughtred is evident from the appearance, over fifty years after the first publication of the Clavis, of a booklet by Gilbert Clark, entitled Oughtredus Explicatus, London, 1682. A review of this appeared in the Acta Eruditorum (Leipzig, I684), on p. I68, wherein Oughtred is named "clarissimus Angliae mathematicus." John Collins wrote Wallis in 1666-67 that Clark, "who lives with Sir Justinian Isham, within seven miles of Northampton, . . . . intimates he wrote a comment on the Clavis, which lay long in the hands of a printer, by whom he was abused, meaning Leybourne." ${ }_{2}$

We shall have occasion below to refer to Oughtred's inability to secure a copy of a noted Italian mathematical work published a few years before. In those days the condition of the book trade in England must have been somewhat extraordinary. Dr. J. W. L. Glaisher throws some light upon this subject. ${ }^{3}$ He found in the Calendar

'Rigaud, op. cit., Vol. II, p. 475. ' $\quad$ Ibid., Vol. II, p. 47 I.

${ }^{3}$ J. W. L. Glaisher, "On Early Logarithmic Tables, and Their Calculators," Philosophical Magazine, 4th Ser., Vol. XLV (1873), pp. 378,379 . 
of State Papers, Domestic Series, 1637 , a petition to Archbishop Laud in which it is set forth that when Hooganhuysen, a Dutchman, "heretofore complained of in the High Commission for importing books printed beyond the seas," had been bound "not to bring in any more," one Vlacq (the computer and publisher of logarithmic tables) "kept up the same agency and sold books in his stead. . . . . Vlacq is now preparing to go beyond the seas to avoid answering his late bringing over nine bales of books contrary to the decree of the Star Chamber." Judgment was passed that, "Considering the ill-consequence and scandal that would arise by strangers importing and venting in this kingdom books printed beyond the seas," certain importations be prohibited, and seized if brought over.

This want of easy intercommunication of results of scientific research in Oughtred's time is revealed in the following letter, written by Oughtred to Robert Keylway, in 1645 :

I speak this the rather, and am induced to a better confidence of your performance, by reason of a geometric-analytical art or practice found out by one Cavalieri, an Italian, of which about three years since I received information by a letter from Paris, wherein was praelibated only a small taste thereof, yet so that I divine great enlargement of the bounds of the mathematical empire will ensue. I was then very desirous to see the author's own book while my spirits were more free and lightsome, but I could not get it in France. Since, being more stept into years, daunted and broken with the sufferings of these disastrous times, I must content myself to keep home, and not put out to any foreign discoveries. ${ }^{x}$

It was in 1655 , when Oughtred was about eighty years old, that John Wallis, the great forerunner of Newton in

${ }^{x}$ Rigaud, op. cit., Vol. I, p. 65. 
Great Britain, began to publish his great researches on the arithmetic of infinites. Oughtred rejoiced over the achievements of his former pupil. In 1655 , Oughtred wrote John Wallis as follows:

I have with unspeakable delight, so far as my necessary businesses, the infirmness of my health, and the greatness of my age (approaching now to an end) would permit, perused your most learned papers, of several choice arguments, which you sent me: wherein I do first with thankfulness acknowledge to God, the Father of lights, the great light he hath given you; and next I congratulate you, even with admiration, the clearness and perspicacity of your understanding and genius, who have not only gone, but also opened a way into these profoundest mysteries of art, unknown and not thought of by the ancients. With which your mysterious inventions I am the more affected, because full twenty years ago, the learned patron of learning, Sir Charles Cavendish, shewed me a paper written, wherein were some few excellent new theorems, wrought by the way, as I suppose, of Cavalieri, which I wrought over again more agreeably to my way. The paper, wherein I wrought it, I shewed to many, whereof some took copies, but my own I cannot find. I mention it for this, because I saw therein a light breaking out for the discovery of wonders to be revealed to mankind, in this last age of the world: which light I did salute as afar off, and now at a nearer distance embrace in your prosperous beginnings. Sir, that you are pleased to mention my name in your never dying papers, that is your noble favour to me, who can add nothing to your glory, but only my applause. . . . I

The last sentence has reference to Wallis' appreciative and eulogistic reference to Oughtred in the preface. It is of interest to secure the opinion of later English writers who knew Oughtred only through his books. John

${ }^{x}$ Rigaud, op. cit., Vol. I, p. 87 . 
Locke wrote in his journal under the date, June 24, I68I, "the best algebra yet extant is Outred's."I John Collins, who is known in the history of mathematics chiefly through his very extensive correspondence with nearly all mathematicians of his day, was inclined to be more critical. He wrote Wallis about 1667 :

It was not my intent to disparage the author, though I know many that did lightly esteem him when living, some whereof are at rest, as Mr. Foster and Mr. Gibson. . . . . You grant the author is brief, and therefore obscure, and I say it is but a collection, which, if himself knew, he had done well to have quoted his authors, whereto the reader might have repaired. You do not like those words of Vieta in his theorems, ex adjunctione plano solidi, plus quadrato quadrati, etc., and think Mr. Oughtred the first that abridged those expressions by symbols; but I dissent, and tell you 'twas done before by Cataldus, Geysius, and Camillus Gloriosus, ${ }^{2}$ who in his first decade of exercises, (not the first tract,) printed at Naples in 1627, which was four years before the first edition of the Clavis, proposeth this equation just as I here give it you, viz. $\mathrm{r} c c c+$ $\mathrm{r} 6 q c c+4 \mathrm{r} q q c-2304 c c-\mathrm{r} 8364 q c-\mathrm{r} 33000 q q-54505 c+3728 q+$ $8064 N$ aequatur 4608 , finds $N$ or a root of it to be 24 , and composeth the whole out of it for proof, just in Mr. Oughtred's symbols and method. Cataldus on Vieta came out fifteen years before, and I cannot quote that, as not having it by me.

.... And as for Mr. Oughtred's method of symbols, this I say to it; it may be proper for you as a commentator to follow it, but divers I know, men of inferior rank that have good skill in algebra, that neither use nor approve it. . . . Is not $A^{5}$ sooner wrote than $A_{q c}$ ? Let $A$ be 2, the cube of 2 is 8 , which squared is 64: one of the questions between Maghet

${ }^{x}$ King's Life of John Locke, Vol. I, London, 1830, p. 227.

${ }^{2}$ Exercitationum Mathematicarum Decas prima, Naples, ${ }^{6} 6_{27}$, and probably Cataldus' Transformatio Geometrica, Bonon., I6I2. 
Grisio and Gloriosus is whether $6_{4}=A_{c c}$ or $A_{q c}$. The Cartesian method tells you it is $A^{6}$, and decides the doubt. . . . .

There is some ground for the criticisms passed by Collins. To be sure, the first edition of the Clavis is dated $1631-$ six years before Descartes suggested the exponential notation which came to be adopted as the symbolism in our modern algebra. But the second edition of the Clavis, I647, appeared ten years after Descartes' innovation. Had Oughtred seen fit to adopt the new exponential notation in 1647 , the step would have been epochmaking in the teaching of algebra in England. We have seen no indication that Oughtred was familiar with Descartes' Géométrie of 1637.

The year preceding Oughtred's death Mr. John Twysden expressed himself as follows in the preface to his Miscellanies:

It remains that I should adde something touching the beginning, and use of these Sciences. . . . . I shall only, to their honours, name some of our own Nation yet living, who have happily laboured upon both stages. That succeeding ages may understand that in this of ours, there yet remained some who were neither ignorant of these Arts, as if they had held them vain, nor condemn them as superfluous. Amongst them all let Mr. William Oughtred, of Aeton, be named in the first place, a Person of venerable grey haires, and exemplary piety, who indeed exceeds all praise we can bestow upon him. Who by an easie method, and admirable Key, hath unlocked the hidden things of geometry. Who by an accurate Trigonometry and furniture of Instruments, hath inriched, as well geometry, as Astronomy. Let D. John Wallis, and D. Seth Ward, succeed in the next place, both famous Persons, and Doctors in Divinity, the one of geometry, the

${ }^{x}$ Rigaud, $o p$. cil., Vol. II, pp. 477-80 
other of astronomy, Savilian Professors in the University of Oxford. ${ }^{x}$

The astronomer Edmund Halley, in his preface to the I694 English edition of the Clavis, speaks of this book as one of "so established a reputation, that it were needless to say anything thereof," though "the concise Brevity of the author is such, as in many places to need Explication, to render it Intelligible to the less knowing Mathematical matters."

In closing this part of our monograph, we quote the testimony of Robert Boyle, the experimental physicist, as given May 8, 1647, in a letter to Mr. Hartlib:

The Englishing of, and additions to Oughtred's Clavis mathematica does much content me, I having formerly spent much study on the original of that algebra, which I have long since esteemed a much more instructive way of logic, than that of Aristotle. ${ }^{2}$

\section{WAS DESCARTES INDEBTED TO OUGHTRED?}

This question first arose in the seventeenth century, when John Wallis, of Oxford, in his Algebra (the English edition of 1685 , and more particularly the Latin edition of r693), raised the issue of Descartes' indebtedness to the English scientists, Thomas Harriot and William Oughtred. In discussing matters of priority between Harriot and Descartes, relating to the theory of equations, Wallis is generally held to have shown marked partiality to Harriot. Less attention has been given by historians

I Miscellanies: or Mathematical Lucubrations, of Mr. Samuel Foster, Sometimes publike Professor of Astronomie in Gresham Colledge in London, by John Twysden, London, 1659 .

${ }^{2}$ The Works of the Honourable Robert Boyle in five volumes, to which is prefixed the Life of the Author, Vol. I, London, I744, P. 24. 
of mathematics to Descartes' indebtedness to Oughtred. Yet this question is of importance in tracing Oughtred's influence upon his time.

On January 8, r688-89, Samuel Morland addressed a letter of inquiry to John Wallis, containing a passage which we translate from the Latin:

Some time ago I read in the elegant and truly precious book that you have written on Algebra, about Descartes, this philosopher so extolled above all for having arrived at a very perfect system by his own powers, without the aid of others, this Descartes, I say, who has received in geometry very great light from our Oughtred and our Harriot, and has followed their track though he carefully suppressed their names. I stated this in a conversation with a professor in Utrecht (where I reside at present). He requested me to indicate to him the page-numbers in the two authors which justified this accusation. I admitted that I could not do so. The Géométrie of Descartes is not sufficiently familiar to me, although with Oughtred I am fairly familiar. I pray you therefore that you will assume this burden. Give me at least those references to passages of the two authors from the comparison of which the plagiarism by Descartes is the most striking. ${ }^{x}$

Following Morland's letter in the De algebra tractatus, is printed Wallis' reply, dated March I2, I688 ("Stilo Angliae"), which is, in part, as follows:

I nowhere give him the name of a plagiarist; I would not appear so impolite. However this I say, the major part of his algebra (if not all) is found before him in other authors (notably in our Harriot) whom he does not designate by name. That algebra may be applied to geometry, and that it is in fact so applied, is nothing new. Passing the ancients in silence, we state that this has been done by Vieta, Ghetaldi, Oughtred

${ }^{x}$ The letter is printed in John Wallis' De algebra tractatus, 1693, p. 206 . 
and others, before Descartes. They have resolved by algebra and specious arithmetic [literal arithmetic] many geometrical problems. . . . . But the question is not as to application of algebra to geometry (a thing quite old), but of the Cartesian algebra considered by itself.

Wallis then indicates in the 1659 edition of Descartes' Géométrie where the subjects treated on the first six pages are found in the writings of earlier algebraists, particularly of Harriot and Oughtred. For example, what is found on the first page of Descartes, relating to addition, subtraction, multiplication, division, and root extraction, is declared by Wallis to be drawn from Vieta, Ghetaldi, and Oughtred.

It is true that Descartes makes no mention of modern writers, except once of Cardan. But it was not the purpose of Descartes to write a history of algebra. To be sure, references to such of his immediate predecessors as he had read would not have been out of place. Nevertheless, Wallis fails to show that Descartes made illegitimate use of anything he may have seen in Harriot or Oughtred.

The first inquiry to be made is, Did Descartes possess copies of the books of Harriot and Oughtred? It is only in recent time that this question has been answered as to Harriot. As to Oughtred, it is still unanswered. It is now known that Descartes had seen Harriot's Artis analyticae praxis (163I). Descartes wrote a letter to Constantin Huygens in which he states that he is sending Harriot's book. ${ }^{\text {. }}$

An able discussion of the question, what effect, if any, Oughtred's Clavis mathematicae of $\mathrm{I}^{6} 3 \mathrm{I}$ had upon

${ }^{x}$ See La Correspondance de Descartes, published by Charles Adam and Paul Tannery, Vol. II, Paris, I898, pp. $45^{6}$ and 457. 
Descartes' Géométrie of ${ }^{16} 37$, is given by H. Bosmans in a recent article. According to Bosmans no evidence has been found that Descartes possessed a copy of Oughtred's book, or that he had examined it. Bosmans believes nevertheless that Descartes was influenced by the Clavis, either directly or indirectly. He says:

If Descartes did not read it carefully, which is not proved, he was none the less well informed with regard to it. No one denies his intimate knowledge of the intellectual movement of his time. The Clavis mathematica enjoyed a rapid success. It is impossible that, at least indirectly, he did not know the more original ideas which it contained. Far from belittling Descartes, as I much desire to repeat, this rather makes him the greater. ${ }^{2}$

We ourselves would hardly go as far as does Bosmans. Unless Descartes actually examined a copy of Oughtred it is not likely that he was influenced by Oughtred in appreciable degree. Book reviews were quite unknown in those days. No evidence has yet been adduced to show that Descartes obtained a knowledge of Oughtred by correspondence. A most striking feature about Oughtred's Clavis is its notation. No trace of the Englishman's symbolism has been pointed out in Descartes' Géométrie of 1637 . Only six years intervened between the publication of the Clavis and the Géométrie. It took longer than this period for the Clavis to show evidence of its influence upon mathematical books published in England; it is not probable that abroad the contact was more immediate

${ }^{x}$ H. Bosmans, S.J., "La première édition de la Clavis Mathematica d'Oughtred. Son influence sur la Géométrie de Descartes," Annales de la sociêté scientifique de Bruxelles, 35th year, I910-II, Part II, pp. $24-78$.

${ }^{2}$ Ibid., p. 78. 
than at home. Our study of seventeenth-century algebra has led us to the conviction that Oughtred deserves a higher place in the development of this science than is usually accorded to him; but that it took several decennia for his influence fully to develop.

\section{THE SPREAD OF OUGHTRED'S NOTATIONS}

An idea of Oughtred's influence upon mathematical thought and teaching can be obtained from the spread of his symbolism. This study indicates that the adoption was not immediate. The earliest use that we have been able to find of Oughtred's notation for proportion, $A . B:$ : $C . D$, occurs nineteen years after the Clavis mathematicae of I63r. In I650 John Kersey brought out in London an edition of Edmund Wingates' Arithmetique made easie, in which this notation is used. After this date publications employing it became frequent, some of them being the productions of pupils of Oughtred. We have seen it in Vincent Wing (I65I), ${ }^{x}$ Seth Ward (I653), John Wallis (1655), ${ }^{3}$ in "R. B.," a schoolmaster in Suffolk, ${ }^{4}$ Samuel Foster (I659), ${ }^{5}$ Jonas Moore (I660), ${ }^{6}$ and Isaac Barrow $(1657) .7$ In the latter part of the seventeenth century

${ }^{x}$ Vincent Wing, Harmonicon coeleste, London, I65I, p. 5.

${ }^{2}$ Seth Ward, In Ismaelis Bullialdi astronomiae philolaicae fundamenia inquisitio brevis, Oxford, 1653, p. 7 .

3 John Wallis, Elenchus geometriae Hobbianae, Oxford, 1655, p. 48.

${ }^{4}$ An Idea of Arithmetick, at first designed for the use of the Free Schoole at Thurlow in Suffolk. . . . By R. B., Schoolmaster there, London, 1655 , p. 6.

${ }^{5}$ The Miscellanies: or Mathematical Lucubrations, of Mr. Samuel Foster . . . . by John Twysden, London, I659, p. I.

${ }^{6}$ Moor's Arithmetick in two Books, London, 1660, p. 89.

7 Isaac Barrow, Euclidis data, Cambridge, I657, p. 2. 
Oughtred's notation, A.B::C.D, became the prevalent, though not universal, notation in Great Britain. A tremendous impetus to their adoption was given by Seth Ward, Isaac Barrow, and particularly by John Wallis, who was rising to international eminence as a mathematician.

In France we have noticed Oughtred's notation for proportion in Franciscus Dulaurens ( 1667$),{ }^{\mathrm{I}} \mathrm{J}$. Prestet (I675), ${ }^{2}$ R. P. Bernard Lamy (I684), ${ }^{3}$ Ozanam (I69I), ${ }^{4}$ De l'Hospital $(\mathrm{r} 696,)^{5}$ R. P. Petro Nicolas ( 1697$) 6^{6}$

In the Netherlands we have noticed it in R. P. Bernard Lamy (r680), ${ }^{7}$ and in an anonymous work of $1690 .^{8}$ In German and Italian works of the seventeenth century we have not seen Oughtred's notation for proportion.

In England a modified notation soon sprang up in which ratio was indicated by two dots instead of a single dot, thus $A: B:: C: D$. The reason for the change lies probably in the inclination to use the single dot to designate decimal fractions. W. W. Beman pointed out that this modified symbolism (:) for ratio is found as early as 1657 in the end of the trigonometric and logarithmic

${ }^{1}$ Francisci Dulaurens Specima mathematica, Paris, I667, p. I.

${ }^{2}$ Elémens des mathématiques, Paris, I675, Preface signed "J. P."

${ }^{3}$ Nouveaux élémens de géométrie, Paris, $\mathrm{I}^{2} 9_{2}$ (permission to print I684).

${ }^{4}$ Ozanam, Dictionnaire mathématique, Paris, I69I, p. 12.

${ }^{5}$ Analyse des infiniment petits, Paris, I696, p. Ir.

${ }^{6}$ Petro Nicolas, De conchoidibus et cissoidibus exercitationes geometricae, Toulouse, 1697, p. 17.

${ }^{7}$ R. P. Bernard Lamy, Elémens des mathématiques, Amsterdam, I692 (permission to print I680).

${ }^{8}$ Nouveaux élémens de géométrie, $2 \mathrm{~d}$ ed., The Hague, I69o, p. 304 . 
tables that were bound with Oughtred's Trigonometria. ${ }^{\mathrm{x}}$ It is not probable, however, that this notation was used by Oughtred himself. The Trigonometria proper has Oughtred's A.B::C.D throughout. Moreover, in the English edition of this trigonometry, which appeared the same year, $\mathrm{I}_{57}$, but subsequent to the Latin edition, the passages which contained the colon as the symbol for ratio, when not omitted, are recast, and the regular Oughtredian notation is introduced. In Oughtred's posthumous work, Opuscula mathematica hactenus inedita, I677, the colon appears quite of ten but is most likely due to the editor of the book.

We have noticed that the notation $A: B:: C: D$ antedates the year 1657 . Vincent Wing, the astronomer, published in ${ }^{1} 65^{1} \mathrm{I}$ in London the Harmonicon coeleste, in which is found not only Oughtred's notation $A . B:: C . D$ but also the modified form of it given above. The two are used interchangeably. His later works, the Logistica astronomica (1656), Doctrina spherica (1655), and Doctrina theorica, published in one volume in London, all use the symbols $A: B:: C: D$ exclusively. The author of a book entitled, An Idea of Arithmetick at first designed for the use of the Free Schoole at Thurlow in Suffolk . . . by $R$. B., Schoolmaster there, London, $6_{55}$, writes $A: a:: C: c$, though part of the time he uses Oughtred's unmodified notation.

We can best indicate the trend in England by indicating the authors of the seventeenth century whom we have found using the notation $A: B:: C: D$ and the authors of the eighteenth century whom we have found using $A$. B: : $C . D$. The former notation was the less common during

${ }^{x} \mathrm{~W}$. W. Beman in L'intermédiaire des mathématiciens, Paris, Vol. IX, 1902, p. 229, question 2424 . 
the seventeenth but the more common during the eighteenth century. We have observed the symbols $A: B:$ : $C: D$ (besides the authors already named) in John Collins (I659), ${ }^{\mathrm{I}}$ James Gregory (I663), ${ }^{2}$ Christopher Wren (I66869), ${ }^{3}$ William Leybourn (I673), ${ }^{4}$ William Sanders (I686), ${ }^{5}$ John Hawkins (I684), ${ }^{6}$ Joseph Raphson (I697), ${ }^{7}$ E. Wells (I698), ${ }^{8}$ and John Ward (I698). ${ }^{9}$

Of English eighteenth-century authors the following still clung to the notation A.B::C.D: John Harris' translation of F. Ignatius Gaston Pardies (I 701 ) ${ }^{\text {10 }}$ George Shelley (I704), ${ }^{11}$ Sam Cobb (I709), ${ }^{12}$ J. Collins in Commercium Epistolicum (I7I2), John Craig (I7I8), ${ }^{\mathrm{x}}$ Jo.

' John Collins, The Mariner's Plain Scale New Plain'd, London, 1659, p. 25.

${ }^{2}$ James Gregory, Optica promota, London, 1663, pp. 19, 48.

3 Philosophical Transactions, Vol. III, London, p. 868.

${ }_{4}$ William Leybourn, The Line of Proportion, London, 1673, p. 14.

${ }^{5}$ Elementa geometriae . . . a a Gulielmo Sanders, Glasgow, r686, p. 3 .

${ }^{6}$ Cocker's Decimal Arithmetick, . . . . perused by John Hawkins, London, I695 (preface dated I684), p. 4I.

${ }^{7}$ Joseph Raphson, Analysis Aequationum universalis, London, I697, p. 26.

${ }^{8}$ E. Wells, Elementa arithmeticae numerosae et speciosae, Oxford ז698, p. 107 .

9 John Ward, A Compendium of Algebra, 2d ed., London, I698, p. 62 .

ro Plain Elements of Geometry and Plain Trigonometry, London, I 70I, p. 63.

${ }^{2 x}$ George Shelley, Wingate's Arithmetick, London, 1704, p. 343.

${ }^{12}$ A Synopsis of Algebra, Being a posthumous work of John Alexander of Bern, Swisserland. . . . Done from the Latin by Sam. Cobb, London, I709, p. 16.

${ }^{13}$ John Craig, De Calculo fluentium, London, 1718, p. 35. The notation $A: B:: C: D$ is given also. 
Wilson (1724). $\quad$ The latest use of $A . B:: C . D$ which has come to our notice is in the translation of the Analytical Institutions of Maria G. Agnesi, made by John Colson sometime before 1760 , but which was not published until r8or. During the seventeenth century the notation $A: B:: C: D$ acquired almost complete ascendancy in England.

In France Oughtred's unmodified notation $A . B:: C . D$, having been adopted later, was also discarded later than in England. An approximate idea of the situation appears from the following data. The notation $A . B .: C . D$ was used by M. Carré (I700), ${ }^{2}$ M. Guisnée (I705), ${ }^{3}$ M. de Fontenelle (I 27$),{ }^{4}$ M. Varignon (I 25$),{ }^{5}$ M. Robillard (I753), ${ }^{6}$ M. Sebastien le Clerc (I764), ${ }^{7}$ Clairaut (I73I), ${ }^{8}$ M. L'Hospital (r78r). ${ }^{9}$

In Italy Oughtred's modified notation $a, b:: c, d$ was used by Maria G. Agnesi in her Instituzioni analitiche,

I Trigonometry, 2d ed., Edinburgh, I724, p. II.

${ }^{2}$ Méthode pour la mésure des surfaces, la dimension des solides . . . par M. Carré de l'académie r. des sciences, I700, p. 59.

3 Application de l'algèbre à géométrie . . . . Paris, 5705 .

4 Elémens de la géométrie de l'infini, by M. de Fontenelle, Paris, I 727 , p. I Io.

5 Eclaircissemens sur l'analyse des infiniment petits, by M. Varignon, Paris, $\mathrm{r}_{725}$, p. 87 .

${ }^{6}$ Application de la géométrie ordinaire et des calculs différentiel et intégral, by M. Robillard, Paris, 1753 .

7 Traité de gêométrie théorique et pratique, new ed., Paris, 1764 , p. 15 .

${ }^{8}$ Recherches sur les courbes à double courbure, Paris, I73I, p. I3.

${ }^{9}$ Analyse des infiniment petits, by the Marquis de L'Hospital. New ed. by M. Le Fèvre, Paris, 178r, p. 4r. In this volume passages in fine print, probably supplied by the editor, contain the notation $a: b:: c: d$; the parts in large type give Oughtred's original notation. 
Milano, I748. The notation $a: b:: c: d$ found entrance the latter part of the eighteenth century. In Germany the symbolism $a: b=c: d$, suggested by Leibniz, found wider acceptance. ${ }^{\mathrm{x}}$

It is evident from the data presented that Oughtred proposed his notation for ratio and proportion at a time when the need of a specific notation began to be generally felt, that his symbol for ratio $a . b$ was temporarily adopted in England and France but gave way in the eighteenth century to the symbol $a: b$, that Oughtred's symbol for proportion : : found almost universal adoption in England and France and was widely used in Italy, the Netherlands, the United States, and to some extent in Germany; it has survived to the present time but is now being gradually displaced by the sign of equality $=$.

Oughtred's notation to express aggregation of terms has received little attention from historians but is never-

${ }^{x}$ The tendency during the eighteenth century is shown in part by the following data: Jacobi Bernoulli Opera, Tomus primus, Geneva, I 744, gives $B . A:: D . C$ on p. 368 , the paper having been first published in $\mathrm{I} 688$; on p. $4 \mathrm{I} 9$ is given $G E: A G=L A: M L$, the paper having been first published in 1689. Bernhardi Nieuwentiit, Considerationes circa analyseos ad quantitates infinilè parvas applicatae principia, Amsterdam, 1694, p. 20, and Analysis infinitorum, Amsterdam, 1695, on p. 276, have $x: c:: s: r$. Paul Halcken's Deliciae mathematicae, Hamburg, I7I 9 , gives $a: b:: c: d$. Johannis Baptistae Caraccioli, Geometria algebraica universa, Rome, 1759, p. 79, has $a . b:: c . d$. Delle corde ouverto fibre elastiche schediasmi fisicomatematici del conte Giordano Riccati, Bologna, 1767, p. 65, gives $P: b$ $:: r: d s$. "Produzioni mathematiche" del Conte Giulio Carlo de Fagnano, Vol. I, Pesario, I750, p. I93, has a.b::c.d. L. Mascheroni, Géométrie du compas, translated by A. M. Carette, Paris, I798, p. I88, gives $\sqrt{3}: 2:: \sqrt{2}: L p$. Danielis Melandri and Paulli Frisi, De theoria lunae commentarii, Parma, I769, p. I3, has $a: b:: c: d$. Vicentio Riccato and Hieronymo Saladino, Institutiones analyticae, Vol. I, Bologna, I765, p. 47, gives $x: a:: m: n+m$. R. G. Boscovich, 
theless interesting. His books, as well as those of John Wallis, are full of parentheses but they are not used as symbols of aggregation in algebra; they are simply marks of punctuation for parenthetical clauses. We have seen that Oughtred writes $(a+b)^{2}$ and $\sqrt{a+b}$ thus, $Q: a+b:$, $\checkmark: a+b:$, or $Q: a+b, \sqrt{ }: a+b$, using on rarer occasions a single dot in place of the colon. This notation did not originate with Oughtred, but, in slightly modified form, occurs in writings from the Netherlands. In $1603 C$. Dibvadii in geometriam Evclidis demonstratio numeralis, Leyden, contains many expressions of this sort, $V \cdot{ }_{13} 6+$ $\sqrt{2048}$, signifying $V^{\prime}\left(\mathrm{I}_{3} 6+\sqrt{ }{ }^{2048}\right)$. The dot is used to indicate that the root of the binomial (not of ${ }_{13} 6$ alone) is called for. This notation is used extensively in Ludolphi a Cevlen de circulo, Leyden, $16 \mathrm{I} 9$, and in Willebrordi Snellii De circuli dimensione, Leyden, I621. In place of the single dot Oughtred used the colon (:), probably

Opera pertinentia ad opticam et astronomiam, Bassani, 1785, p. 409, uses $a: b:: c: d$. Jacob Bernoulli, Ars Conjectandi, Basel, $\mathrm{I}_{71} \mathrm{3}$, has $n-r . n-\mathrm{r}:: c . d$. Pavlini Chelvicii, Institutiones analyticae, editio post tertiam Romanam prima in Germania, Vienna, $176 \mathrm{r}, \mathrm{p} .2, a . b$ : : c.d. Christiani Wolfii, Elementa matheseos universae, Vol. III, Genéva, 1735, p. 63, has $A B: A E=\mathrm{r}: q$. Johann Bernoulli, Opera omnia, Vol. I, Lausanne and Geneva, I742, p. 43, has $a: b=c: d$. D. C. Walmesley, Analyse des mesures des rapports et des angles, Paris, I749, uses extensively $a . b:: c . d$, later $a: b:: c: d$. G. W. Krafft, Institutiones geometriae sublimoris, Tübingen, I753, p. 194, has $a: b=c: d$. J. H. Lambert, Photometria, $\mathbf{1 7 6 0 ,}$. 104, has $C: \pi=$ $B C^{2}: M H^{2}$. Meccanica sublime del Dott. Domenico Bartaloni, Naples, $\mathrm{I} 765$, has $a: b:: c: d$. Occasionally ratio is not designated by $a . b$, nor by $a: b$, but by $a, b$, as for instance in A. de Moivre's Doctrine of Chance, London, $1756, \mathrm{p} .34$, where he writes $a, b:: \mathrm{r}, q$. A further variation in the designation of ratio is found in James Atkinson's Epitome of the Art of Navigation, London, 1718, p. 24, namely, $3 . .2:: 72 . .48$. Curious notations are given in Rich. Balam's Algebra, London, 1653 . 
to avoid confusion with his notation for ratio. To avoid further possibility of uncertainty he usually placed the colon both before and after the algebraic expression under aggregation. This notation was adopted by John Wallis and Isaac Barrow. It is found in the writings of Descartes. Together with Vieta's horizontal bar, placed over two or more terms, it constituted the means used almost universally for denoting aggregation of terms in algebra. Before Oughtred the use of parentheses had been suggested by Clavius $^{\mathrm{I}}$ and Girard. ${ }^{2}$ The latter wrote, for instance, $\sqrt{ }(2+\sqrt{3})$. While parentheses never became popular in algebra before the time of Leibniz and the Bernoullis they were by no means lost sight of. We are able to point to the following authors who made use of them: I. Errard de Bar-le-Duc (I6 I9), ${ }^{3}$ Jacobo de Billy (r643), ${ }^{4}$ one of whose books containing this notation was translated into English, and also the posthumous works of Samuel Foster. ${ }^{5}$ J. W. L. Glaisher points out that parentheses were used by Norwood in his Trigonometrie (163I), p. $30 .^{6}$

${ }^{x}$ Chr. Clavii Operum mathematicorum tomus secundus, Mayence, I6I I, Algebra, p. 39.

${ }^{2}$ Invention nouvelle en l'algèbre, by Albert Girard, Amsterdam, I629, p. 17 .

${ }^{3}$ La géométrie et pratique générale d'icelle, par I. Errard de Bar-leDuc, Ingénieur ordinaire de sa Majesté, 3 d ed., revised by D. H. P. E. M., Paris, I6r9, p. 216.

${ }^{4}$ Novae geometriae clavis algebra, authore $P$. Jacobo de Billy, Paris, 1643, p. I57; also an Abridgement of the Preccpts of Algebra. Written in French by James de Billy, London, r659, p. 346.

s Miscellanies: or Mathematical Lucubrations, of $\mathrm{Mr}$. Samuel Foster, Sometime publike Professor of Astronomie in Gresham Colledge in London, London, 1659, p. 7.

${ }^{6}$ Quarterly Jour. of Pure and Applied Math., Vol. XLVI (London, I9I 5), p. 19r. 
The symbol for the arithmetical difference between two numbers, $\sim$, is usually attributed to John Wallis, but it occurs in Oughtred's Clavis mathematicae of $\mathbf{1 6}_{52}$, in the tract on Elementi decimi Euclidis declaratio, at an earlier date than in any of Wallis' books. As Wallis assisted in putting this edition through the press it is possible, though not probable, that the symbol was inserted by him. Were the symbol Wallis', Oughtred would doubtless have referred to its origin in the preface. During the eighteenth century the symbol found its way into foreign texts even in far-off Italy. ${ }^{\mathrm{I}}$ It is one of three symbols presumably invented by Oughtred and which are still used at the present time. The others are $X$ and : :.

The curious and ill-chosen symbols, $\square$ for "greater than," and _ f for "less than," were certain to succumb in their struggle for existence against Harriot's admirably chosen $>$ and $<$. Yet such was the reputation of Oughtred that his symbols were used in England quite extensively during the seventeenth and the beginning of the eighteenth century. Considerable confusion has existed among algebraists and also among historians as to what Oughtred's symbols really were. Particularly is this true of the sign for "less than" which is frequently written $\sqsupset$. Oughtred's symbols, or these symbols turned about in some way, have been used by Seth Ward, ${ }^{2}$ John Wallis, ${ }^{3}$ Isaac Barrow, ${ }^{4}$

I Pietro Cossali, Origine, trasporto in Italia primi progressi in essa dell' algebra, Vol. I, Parmense, I797, p. 52.

${ }^{2}$ In Is. Bullialdi astronomiae philolaicae fundamenta inquisitio brevis, Auctore Setho Wardo, Oxford, 1653, p. I.

${ }^{3} \mathrm{John}$ Wallis, Algebra, London, r685, p. $32 \mathrm{I}$, and in some of his other works. He makes greater use of Harriot's symbols.

4 Euclidis data, 1657 , p. I; also Euclidis elementorum libris $X V$, London, I659, p. 1 . 
John Kersey, ${ }^{1}$ E. Wells, ${ }^{2}$ John Hawkins, ${ }^{3}$ Tho. Baker, ${ }^{4}$ Richard Sault, ${ }^{5}$ Richard Rawlinson, ${ }^{6}$ Franciscus Dulaurens, ${ }^{7}$ James Milnes, ${ }^{8}$ George Cheyne, ${ }^{9}$ John Craig, ${ }^{\text {,o }}$ Jo. Wilson, ${ }^{11}$ and J. Collins. ${ }^{12}$

General acceptance has been accorded to Oughtred's symbol $X$. The first printed appearance of this symbol for multiplication in 1618 in the form of the letter $x$ hardly explains its real origin. The author of the "Appendix" (be he Oughtred or someone else) may not have used the letter $x$ at all, but may have written the cross $\mathrm{X}$, called the St. Andrew's cross, while the printer, in the absence of any type accurately representing that cross, may have substituted the letter $x$ in its place. The hypothesis that the symbol $\times$ of multiplication owes its origin to the old habit of using directed bars to indicate that two

I John Kersey, Algebra, London, 1673, p. 321.

${ }^{2}$ E. Wells, Elementa arithmeticae numerosae ct speciosae, Oxford, I698, p. 142.

${ }^{3}$ Cocker's Decimal Arithmetick, perused by John Hawkins, London, r695 (preface dated r684), p. 278.

${ }_{4}^{4}$ Th. Baker, The Geometrical Key, London, I684, p. I5.

${ }^{5}$ Richard Sault, A New Treatise of Algebra, London (no date).

${ }^{6}$ Richard Rawlinson in a pamphlet without date, issued sometime between 1655 and 1668 , containing trigonometric formulas. There is a copy in the British Museum.

${ }^{7}$ F. Dulaurens, Spccima mathematica, Pars, I667, p. I.

${ }^{8} \mathrm{~J}$. Milnes, Sectionum gonicarum elementa, Oxford, 1702, p. 42.

9 Cheyne, Philosophical Principles of Natural Religion, London, I 705, p. 55 .

${ }^{20} \mathrm{~J}$. Craig, De calculo fluentium, London, I718, p. 86.

${ }^{n}$ Jo. Wilson, Trigonometry, 2d ed., Edinburgh, I724, p. v.

s2 Commercium Epistolicum, I7 I2, p. 20. 
numbers are to be combined, as for instance in the multiplication of 23 and 34 , thus,

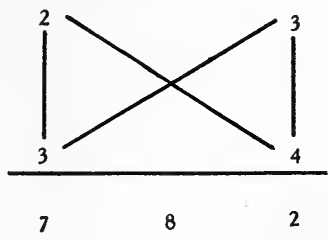

has been advanced by two writers, C. Le Paige ${ }^{\mathrm{x}}$ and Gravelaar. ${ }^{2}$ Bosmans is more inclined to the belief that Oughtred adopted the symbol somewhat arbitrarily, much as he did the numerous symbols in his Elementi decimi Euclidis declaratio. ${ }^{3}$

Le Paige's and Gravelaar's theory finds some support in the fact that the cross $X$, without the two additional vertical lines shown above, occurs in a commentary published by Oswald Schreshensuchs ${ }^{4}$ in I $_{55} \mathrm{I}$, where the sign is written between two factors placed one above the other.

${ }^{x}$ C. Le Paige, "Sur l'origine de certains signes d'opération," Annales de la sociêtế scientifique de Bruxelles, I6th year, 1891-92, Part II, pp. 79-82.

2 Gravelaar, "Over den oorsprong van ons maalteeken $(X), "$ Wiskundig Tijdschrift, 6th year. We have not had access to this article.

${ }^{3} \mathrm{H}$. Bosmans, op. cit., p. 40.

4 Claudii Ptolemaei . . . . annotationes, Bâle, I55I. This reference is taken from the Encyclopédie des sciences mathématiques, Tome I, Vol. I, Fasc. I, p. 40. 


\section{CHAPTER V}

\section{OUGHTRED'S IDEAS ON THE TEACHING OF MATHEMATICS}

\section{GENERAL STATEMENT}

Nowhere has Oughtred given a full and systematic exposition of his views on mathematical teaching. Nevertheless, he had very pronounced and clear-cut ideas on the subject. That a man who was not a teacher by profession should have mature views on teaching is most interesting. We gather his ideas from the quality of the books he published, from his prefaces, and from passages in his controversial writing against Delamain. As we proceed to give quotations unfolding Oughtred's views, we shall observe that three points receive special emphasis: (I) an appeal to the eye through suitable symbolism; (2) emphasis upon rigorous thinking; (3) the postponement of the use of mathematical instruments until after the logical foundations of a subject have been thoroughly mastered.

The importance of these tenets is immensely reinforced by the conditions of the hour. This voice from the past speaks wisdom to specialists of today. Recent methods of determining educational values and the modern cult of utilitarianism have led some experts to extraordinary conclusions. Laboratory methods of testing, by the narrowness of their range, often mislead. Thus far they have been inferior to the word of a man of experience, insight, and conviction. 
Mathematics, "A SCIENCE OF THE Eye"

Oughtred was a great admirer of the Greek mathematicians-Euclid, Archimedes, Apollonius of Perga, Diophantus. But in reading their works he experienced keenly what many modern readers have felt, namely, that the almost total absence of mathematical symbols renders their writings unnecessarily difficult to read. Statements that can be compressed into a few well-chosen symbols which the eye is able to survey as a whole are expressed in long-drawn-out sentences. A striking illustration of the importance of symbolism is afforded by the history of the formula

$$
i x=\log (\cos x+i \sin x) .
$$

It was given in Roger Cotes' Harmonia mensurarum, I722, not in symbols, but expressed in rhetorical form, destitute of special aids to the eye. The result was that the theorem remained in the book undetected for 185 years and was meanwhile rediscovered by others. Owing to the prominence of Cotes as a mathematician it is very improbable that such a thing could have happened had the theorem been thrust into view by the aid of mathematical symbols.

In studying the ancient authors Oughtred is reported to have written down on the margin of the printed page some of the theorems and their proofs, expressed in the symbolic language of algebra.

In the preface of his Clavis of $\mathrm{I}_{3} \mathrm{I}$ and of $\mathrm{I} 647$ he says:

Wherefore, that I might more clearly behold the things themselves, I uncasing the Propositions and Demonstrations out of their covert of words, designed them in notes and species appearing to the very eye. After that by comparing the divers 
affections of Theorems, inequality, proportion, affinity, and dependence, I tryed to educe new out of them.

It was this motive which led him to introduce the many abbreviations in algebra and trigonometry to which reference has been made in previous pages. The pedagogical experience of recent centuries has indorsed Oughtred's view, provided of course that the pupil is carefully taught the exact meaning of the symbols. There have been and there still are those who oppose the intensive use of symbolism. In our day the new symbolism for all mathematics, suggested by the school of Peano in Italy, can hardly be said to be received with enthusiasm. In Oughtred's day symbolism was not yet the fashion. To be convinced of this fact one need only open a book of Edmund Gunter, with whom Oughtred came in contact in his youth, or consult the Principia of Sir Isaac Newton, who flourished after Oughtred. The mathematical works of Gunter and Newton, particularly the former, are surprisingly destitute of mathematical symbols. The philosopher Hobbes, in a controversy with John Wallis, criticized the latter for that "Scab of Symbols," whereupon Wallis replied:

I wonder how you durst touch M. Oughtred for fear of catching the Scab. For, doubtlesse, his book is as much covered over with the Scab of Symbols, as any of mine. . . . . As for my Treatise of Conick Sections, you say, it is covered over with the Scab of Symbols, that you had not the patience to examine whether it is well or ill demonstrated. ${ }^{x}$

${ }^{2}$ Due Correction for Mr. Hobbes. Or Schoole Discipline, for not saying his Lessons right. In answer to his Six Lessons, directed to the Professors of Mathematicks. By the Professor of Geometry. Oxford, 1656, pp. 7, 47, 5 0. 
Oughtred maintained his view of the importance of symbols on many different occasions. Thus, in his Circles of Proportion, I632, p. 20:

This manner of setting downe Theoremes, whether they be Proportions, or Equations, by Symboles or notes of words, is most excellent, artificiall, and doctrinall. Wherefore I earnestly exhort every one, that desireth though but to looke into these noble Sciences Mathematicall, to accustome themselves unto it: and indeede it is easie, being most agreeable to reason, yea even to sence. And out of this working may many singular consectaries be drawne: which without this would, it may be, for ever lye hid.

\section{RIGOROUS THINKING AND THE USE OF INSTRUMENTS}

The author's elevated concept of mathematical study as conducive to rigorous thinking shines through the following extract from his preface to the $\mathrm{I}_{47}$ Clavis:

.... Which Treatise being not written in the usuall synthetical manner, nor with verbous expressions, but in the inventive way of Analitice, and with symboles or notes of things instead of words, seemed unto many very hard; though indeed it was but their owne diffidence, being scared by the newnesse of the delivery; and not any difficulty in the thing it selfe. For this specious and symbolicall manner, neither racketh the memory with multiplicity of words, nor chargeth the phantasie with comparing and laying things together; but plainly presenteth to the eye the whole course and processe of every operation and argumentation.

Now my scope and intent in the first Edition of that my Key was, and in this New Filing, or rather forging of it, is, to reach out to the ingenious lovers of these Sciences, as it were Ariadnes thread, to guide them through the intricate Labyrinth of these studies, and to direct them for the more easie and full understanding of the best and antientest Authors..... 
That they may not only learn their propositions, which is the highest point of Art that most Students aime at; but also may perceive with what solertiousnesse, by what engines of aequations, Interpretations, Comparations, Reductions, and Disquisitions, those antient Worthies have beautified, enlarged, and first found out this most excellent Science. . . . L Lastly, by framing like questions problematically, and in a way of Analysis, as if they were already done, resolving them into their principles, I sought out reasons and means whereby they might be effected. And by this course of practice, not without long time, and much industry, I found out this wåy for the helpe and facilitation of Art.

Still greater emphasis upon rigorous thinking in mathematics is laid in the preface to the Circles of Proportion and in some parts of his Apologeticall Epistle against Delamain. In that preface William Forster quotes the reply of Oughtred to the question how he (Oughtred) had for so many years concealed his invention of the slide rule from himself (Forster) whom he had taught so many other things. The reply was:

That the true way of Art is not by Instruments, but by Demonstration: and that it is a preposterous course of vulgar Teachers, to begin with Instruments, and not with the Sciences, and so in-stead of Artists, to make their Scholers only doers of tricks, and as it were Iuglers: to the despite of Art, losse of previous time, and betraying of willing and industrious wits, vnto ignorance, and idlenesse. That the vse of Instruments is indeed excellent, if a man be an Artist: but contemptible, being set and opposed to Art. And lastly, that he meant to commend to me, the skill of Instruments, but first he would haue me well instructed in the Sciences."

Delamain took a different view, arguing that instruments might very well be placed in the hands of pupils from the start. At the time of this controversy Delamain ${ }^{*}$ 
supported himself by teaching mathematics in London and he advertised his ability to give instruction in mathematics, including the use of instruments. Delamain brought the charge against Oughtred of unjustly calling "many of the [British] Nobility and Gentry doers of trickes and juglers." To this Oughtred replies:

As I did to Delamain and to some others, so I did to William Forster: I freely gave him my helpe and instruction in these faculties: only this was the difference, I had the very first moulding (as I may say) of this latter: But Delamain was already corrupted with doring upon Instruments, and quite lost from ever being made an Artist: I suffered not William Forster for some time so much as speake of any Instrument, except only the Globe it selfe; and to explicate, and worke the questions of the Sphaere, by the way of the Analemma: which also himselfe did describe for the present occasion. And this my restraint from such pleasing avocations, and holding him to the strictnesse of percept, brought forth this fruit, that in short time, even by his owne skill, he could not onely use any Instrument he should see, but also was able to delineate the like, and devise others. ${ }^{x}$

As representing Delamain's views, we make the following selection from his Grammelogia (London, about r633), the part near the end of the book and bearing the title, "In the behalfe of vulgar Teachers and others," where Delamain refers to Oughtred's charge that the scholars of "vulgar" teachers are "doers of tricks, as it were iuglers." Delamain says:

. . . Which words are neither cautelous, nor subterfugious, but are as downe right in their plainnesse, as they are touching, and pernitious, by two much derogating from many, and glancing upon many noble personages, with too grosse, if not too base an attribute, in tearming them doers of tricks, as it were to

× Oughtred, Apologeticall Epistle, p. 27. 
inggle: because they perhaps make use of a necessitie in the furnishing of themselves with such knowledge by Practicall Instrumentall operation, when their more weighty negotiations will not permit them for Theoreticall figurative demonstration; those that are guilty of the aspertion, and are touched therewith may answer for themselves, and studie to be more Theoreticall, than Practicall: for the Theory, is as the Mother that produceth the daughter, the very sinewes and life of Practise, the excellencie and highest degree of true Mathematicall Knowledge: but for those that would make but a step as it were into that kind of Learning, whose onely desire is expedition, and facilitie, both which by the generall consent of all are best effected with Instrument, rather then with tedious regular demonstrations, it was ill to checke them so grosly, not onely in what they have Practised, but abridging them also of their liberties with what they may Practise, which aspertion may not easily be slighted off by any glosse or Apologie, without an Ingenuous confession, or some mentall reservation: To which vilification, howsoever, in the behalfe of my selfe, and others, I answer; That Instrumentall operation is not only the Compendiating, and facilitating of $A r t$, but even the glory of it, whole demonstration both of the making, and operation is soly in the science, and to an Artist or disputant proper to be knowne, and so to all, who would truly know the cause of the Mathematicall operations in their originall; But, for none to know the use of a Mathematicall Instrumen[t], except he knowes the cause of its operation, is somewhat too strict, which would keepe many from affecting the $A r t$, which of themselves are ready enough every where, to conceive more harshly of the difficultie, and impossibilitie of attayning any skill therein, then it deserves, because they see nothing but obscure propositions, and perplex and intricate demonstrations before their eyes, whose unsavoury tartnes, to an unexperienced palate like bitter pills is sweetned over, and made pleasant with an Instrumentall compendious facilitic, and made to goe downe the more readily, and yet to retaine the same vertue, and working; And me thinkes in this 
queasy age, all helpes may bee used to procure a stomacke, all bates and invitations to the declining studie of so noble a Science, rather then by rigid Method and generall Lawes to scarre men away. All are not of like disposition, neither all (as was sayd before) propose the same end, some resolve to wade, others to put a finger in onely, or wet a hand: now thus to tye them to an obscure and Theoricall forme of teaching, is to crop their hope, even in the very bud. . . . . The beginning of a mans knowledge even in the use of an Instrument, is first founded on doctrinal precepts, and these precepts may be conceived all along in its use: and are so farre from being excluded, that they doe necessarily concomitate and are contained therein: the practicke being better understood by the doctrinall part, and this later explained by the Instrumentall, making precepts obvious unto sense, and the Theory going along with the Instrument, better informing and inlightning the understanding, etc. vis vnita fortior, so as if that in Phylosophy bee true, Nihil est [in] intellectu quod non prius fuit in sensu.

The difference between Oughtred and Delamain as to the use of mathematical instruments raises important questions. Should the slide rule be placed in the hands of a boy before, or after, he has mastered the theory of logarithms? Should logarithmic tables be withheld from him until the theoretical foundation is laid in the mind of the pupil? Is it a good thing to let a boy use a surveying instrument unless he first learns trigonometry? Is it advisable to permit a boy to familiarize himself with the running of a dynamo before he has mastered the underlying principles of electricity? Does the use of instruments ordinarily discourage a boy from mastery of the theory? Or does such manipulation constitute a natural and pleasing approach to the abstract? On this particular point, who showed the profounder psychological insight, Oughtred or Delamain? 
In July, I9I4, there was held in Edinburgh a celebration of the three-hundredth anniversary of the invention of logarithms. On that occasion there was collected at Edinburgh university one of the largest exhibits ever seen of modern instruments of calculation. The opinion was expressed by an experienced teacher that "weapons as those exhibited there are for men and not for boys, and such danger as there may be in them is of the same character as any form of too early specialization."

It is somewhat of a paradox that Oughtred, who in his student days and during his active years felt himself impelled to invent sun-dials, planispheres, and various types of slide rules-instruments which represent the most original contributions which he handed down to posterity-should discourage the use of such instruments in teaching mathematics to beginners. That without the aid of instruments he himself should have succeeded so well in attracting and inspiring young men constitutes the strongest evidence of his transcendent teaching ability. It may be argued that his pedagogic dogma, otherwise so excellent, here goes contrary to the course he himself followed instinctively in his self-education along mathematical lines. We read that Sir Isaac Newton, as a child, constructed sun-dials, windmills, kites, paper lanterns, and a wooden clock. Should these activities have been suppressed? Ordinary children are simply Isaac Newtons on a smaller intellectual scale. Should their activities along these lines be encouraged or checked?

On the other hand, it may be argued that the paradox alluded to above admits of explanation, like all paradoxes, and that there is no inconsistency between Oughtred's pedagogic views and his own course of development. If he invented sun-dials, he must have had a comprehension 
of the cosmic motions involved; if he solved spherical triangles graphically by the aid of the planisphere, he must have understood the geometry of the sphere, so far as it relates to such triangles; if he invented slide rules, he had beforehand a thorough grasp of logarithms. The question at issue does not involve so much the invention of instruments, as the use by the pupil of instruments already constructed, before he fully understands the theory which is involved. Nor does Sir Isaac Newton's activity as a child establish Delamain's contention. Of course, a child should not be discouraged from manual activity along the line of producing interesting toys in imitation of structures and machines that he sees, but to introduce him to the realm of abstract thought by the aid of instruments is a different proposition, fraught with danger. A boy may learn to use a slide rule mechanically and, because of his ability to obtain practical results, feel justified in foregoing the mastery of underlying theory; or he may consider the ability of manipulating a surveying instrument quite sufficient, even though he be ignorant of geometry and trigonometry; or he may learn how to operate a dynamo and an electric switchboard and be altogether satisfied, though having no grasp of electrical science. Thus instruments draw a youth aside from the path leading to real intellectual attainments and real efficiency; they allure him into lanes which are often blind alleys. Such were the views of Oughtred.

Who was right, Oughtred or Delamain? It may be claimed that there is a middle ground which more nearly represents the ideal procedure in teaching. Shall the slide rule be placed in the student's hands at the time when he is engaged in the mastery of principles? Shall there be an alternate study of the theory of logarithms and of 
the slide rule - on the idea of one hand washing the otheruntil a mastery of both the theory and the use of the instrument has been attained? Does this method not produce the best and most lasting results? Is not this Delamain's actual contention? We leave it to the reader to settle these matters from his own observation, knowledge, and experience.

\section{NEWTON'S COMMENTS ON OUGHTRED}

Oughtred is an author who has been found to be of increasing interest to modern historians of mathematics. But no modern writer has, to our knowledge, pointed out his importance in the history of the teaching of mathematics. Yet his importance as a teacher did receive recognition in the seventeenth century by no less distinguished a scientist than Sir Isaac Newton. On May 25, I694, Sir Isaac Newton wrote a long letter in reply to a request for his recommendation on a proposed new course of study in mathematics at Christ's Hospital. Toward the close of his letter, Newton says:

And now I have told you my opinion in these things, I will give you Mr. Oughtred's, a Man whose judgment (if any man's) may be safely relyed upon. For he in his book of the circles of proposition, in the end of what he writes about Navigation (page 184) has this exhortation to Seamen. "And if," saith he, "the Masters of Ships and Pilots will take the pains in the Journals of their Voyages diligently and faithfully to set down in severall columns, not onely the Rumb they goe on and the measure of the Ships way in degrees, and the observation of Latitude and variation of their compass; but alsoe their conjectures and reason of their correction they make of the aberrations they shall find, and the qualities and condition of their ship, and the diversities and seasons of the winds, and the secret motions or agitations of the Seas, when they begin, and 
how long they continue, how farr they extend and with what inequality; and what else they shall observe at Sea worthy consideration, and will be pleased freely to communicate the same with Artists, such as are indeed skilfull in the Mathematicks and lovers and enquirers of the truth: I doubt not but that there shall be in convenient time, brought to light many necessary precepts which may tend to $y^{e}$ perfecting of Navigation, and the help and safety of such whose Vocations doe inforce them to commit their lives and estates in the vast Ocean to the providence of God." Thus farr that very good and judicious man Mr. Oughtred. I will add, that if instead of sending the Observations of Seamen to able Mathematicians at Land, the Land would send able Mathematicians to Sea, it would signify much more to the improvem ${ }^{t}$ of Navigation and safety of Mens lives and estates on that element. ${ }^{x}$

May Oughtred prove as instructive to the modern reader as he did to Newton!

${ }^{x}$ J. Edleston, Correspondence of Sir Isaac Newton and Professor Cotes, London, 1850, pp. 279-92. 



\section{INDEX}

Adam, Charles, 7I

Agnesi, Maria G., 77

Alexander, J., 76

Allen, E., 35

Analysis, 19, 20

Apollonius of Perga, 20, 85

Archimedes, 18, 20, 85

Aristotle, 69

Ashmole, E., I3

Atkinson, J., 79

Atwood, 56

Aubrey, 3, 7, 8, I 2-I6, 58, 59

Austin, 58

Baker, T., 82

Balam, R., 79

Bar-le-Duc, de, 80

Barrow, S., I, 32, 73, 74, 80, 8 I

Bartaloni, D., 79

Beman, W. W., 74, 75

Bernoulli, Jakob, $78-80$

Bernoulli, John, 79, 80

Billingsley's Euclid, I 5

Billion, 20

Billy, Jacobo de, 80

Binomial formula, 25, 29

Bliss, P., 60

Boscovich, R. G., 78

Bosmans, H., 72, 83

Boyle, R., I, 69

Braunmühl, von, 39

Brearly, W., 59

Briggs, 6, 36, 55

Brookes, Christopher, 7, 53, 59

Cajori, F., 27, 39, 40, 47

Cantor, M., 4O, 4I

Caraccioli, J. B., 78

Cardan, $7 \mathrm{I}$

Carré, 77

Carrete, N. M., 78

Caryll, C., 7
Cataldi, 67

Cavalieri, 65, 66

Cavendish, Charles, I 7, 62, 66

Charles I, 9, 60

Chelvicius, P., 79

Cheyne, G., 82

Circles of Proportion, 35, 37, 48, 49, 5I, 59, 87, 88

Clairaut, 77

Clark, A., 3

Clark, G., 63

Clarke, F. L., 3

Clavis mathematicae, I, 5, 10, I4, I 7-35, 45, 46, 5I, 57-63, 68$73,81,85,87$

Clavius, 26, 80

Clerc, le, 77

Cobb, S., 76

Cocker, 76,82

Collins, John, 15, 19, 63, 64, 67, $68,76,82$

Colson, J., 77

Conchoid, I 2

Conic sections, II, 53

Cossali, P., 8I

Cotes, R., I, 85

Craig, J., 76, 82

Cross, symbol of multiplication, $27,38,55,56,82,83$

Cubic equations, 28, 34, 42, 45

Decimal fractions, notation of, 2 I

Degree, centesimal division, 39

Delamain, R., 4, 9, IO, II , 47, 48, 5I , 60, 84, 88, 89, 9I, 93, 94

De Moivre, 32, 79

De Morgan, A., 5, 16, 37, 46, 47, 54

Descartes, R., I, 25, 47, 57, 6872,80

Dibuadius, 79

Difference, symbol for, $27,8 \mathrm{I}$ 
Diophantus, 63,85

Division, abbreviated, 2I, 23, 24

Dulaurens, F., 74, 82

Earl of Arundel, Io, I3, I5, I 7

Edleston, J., 95

Eneström, G., 40

Equations, solution of, I8, 28, 29, 3r, 34, 39-45, 87

Errard de Bar-le-Duc, 8o

Eton College, 3, 4

Euclid, I, 15, 18, 20, 25, 27, 28, $79,8 \mathrm{I}, 83,85$

Euler, L., 37, 39

Ewart, 59

Exponents, 25, 28, 29

Fagnano, de, 78

Flower, 56

Fontenelle, de, 77

Forster, W., 35, 48, 59, 88

Foster, S., 27, 67, 69, 73, 80, 89

Frisi, P., 78

Gascoigne, 59, 6I

Gauss, C. F., 48

Geysius, 67

Ghetaldi, 70, $7 \mathrm{I}$

Gibson, 67

Girard, A., 32, 80

Glaisher, J. W. L., 54-56, 64, 80

Glorioso, 67, 68

Grammelogia, 4, 47, 89

Gravelaar, 83

Greater than, symbol for, $8 \mathrm{I}$

Greatrex, R., I 5

Gregory, D., 32

Gregory, J., 27, 76

Gresham College, I, 6, 27, 59, 6r , 80

Guisnée, 77

Gunter, E., 37, 47, 86

Gunter's scale, 37

Halcken, P., 78

Hales, J., 7

Halley, E., I, I8, 69

Hankel, H., 40

Harper, T., 18
Harriot, T., 45, 47, 57, 58, 69$7 \mathrm{I}, 8 \mathrm{I}$

Harris, J., 76

Hartlib, 69

Haughton, A., 35, 59

Hawkins, J., 76, 82

Hearn, 56

Helmholtz, 48

Henry, J., 48

Henry van Etten, 52, 53

Henshaw, 'T., 8, 58, $6 \mathrm{r}$

Hobbes, 73, 86

Hollar, I4

Holsatus, I3

Hooganhuysen, 64

Hooke, Rb., I

Horner's method, 45

Horology, I8, $5^{\circ}$

Horrox, J., 4

Hospital, de l', 74, 77

Howard, Th. See Earl of Arundel.

Howard, W., I 7, I8, 59

Hutchinson, A., 6

Invisible college, I

Joule, 48

Kepler, J., 6

Kersey, J., 32, 73, 82

Keylway, R., 65

King, 67

Kings College, Cambridge, 3, 35

Krafft, G. W., 79

Lambert, J. H., 79

Lamy, R. P. B., 74

Laud, Archbishop, 65

Leake, W., 53

Le Clerc, 77

Leech, W., 59

Le Fèvre, 77

Leibniz, $47,78,80$

Leonelli, 56

Le Paige, de, 83

Less than, symbol for, 8 I

Leurechon, 52

Leybourn, 35, 64, 76 
Lichfield, Mrs., I9

Lilly, W., 8, 9

Locke, J., 67

Logarithms, 6, 21 , 27, 28, 38, 39, $42,46,54-56,65,92,93$; natural, 55; radix method of computing, 55,56

Lower, W., 58

Ludolph à Ceulen, 79

Manning, 56

Manning, O., 7, 8, I3-15

Mascheroni, L., 78

Mayer, R., 47

Melandri, D., 78

Mercator, N., I3

Mersenne, 63

Milbourn, W., 45

Million, 20

Milnes, J., 82

Moivre, de, 32, 79

Moore, Jonas, 32, 54, 58, 73

Moreland, S., 70

Morse, R., 48

Multiplication, abbreviated, 2I, 22 , 24; symbol for, $27,82,83$

Mydorge, 54

Napier, J., 6, 7, 21, 27, 38, 39, $5^{2}, 54,57,59$

Napier's analogies, 39

Newton, Sir Isaac, I, 25, 29, 40, $4 \mathrm{I}, 45,47,59,65,86,92-95$

Nichols, J., 6, I4

Nicolas, R. P. P., 74

Nieuwentiit, B., 78

Norwood, R., 37, 38, 80

Opuscula mathematica hactenus inedita, 16, 21, 75

Orchard, 56

Oughtredus explicatus, 64

Ozanam, 74

$\pi$, symbol for, $3^{2}$

Paige, C. de, 83

Pardies, 76

Parentheses, 26, 79, 80

Partridge, S., 47
Peano, 86

Perfect number, $4 \mathrm{I}$

Pitiscus, 15

Planisphere, 53, 92, 93

Prestet, J., 74

Price, II

Proportion, notation for, 26,27 , 73-79

Protheroe, 58

Ptolemy, 83

Quadratic equation, 29, 3I, 34

Radix method, 55, 56

Rahn, 27

Raphson, J., 40, 4I, 76

Ratio, notation of, $21,73-80$

Rawlinson, R., 39, 82

Regula falsa, I8

Regular solids, 18

Riccati, G., 78

Riccati, V., 78

Rigaud, 7, I2, I3, I9, 48, 6r-66, 68

Robillard, 77

Robinson, W., I3, 48, 59, 62, 63

Rooke, L., 59, 6r

Saladini, H., 78

Sanders, W., 76

Sault, R., 82

Scarborough, Charles, I6, 54, 58,60

Schooten, Van, I

Schreshensuchs, O., 83

Scratch method, 23

Shakespeare, 52

Shelley, G., 76

Shipley, A. E., I

Shuttleworth, 59

Slide rule, 9, 46-49, 50, 6o, 88, 93

Smethwyck, $5^{8}$

Smith, J., $5^{\circ}$

Snellius, W., 79

Solids, regular, 18

Speidell, John, 38, 55

Spherical triangles, 53, 54, 93

Stokes, R., 35, 36, $5^{8}$

Sudell, 59

Sun dials, 5, 9, 50, 5r, 52, 60, 92 
Tannery, P., $7 \mathrm{r}$

Todhunter, 60

Torporley, 58

Triangles, spherical, 53, 54, 93

Trigonometria, 21 , 36, 55, 75

Trigonometric functions, symbols for, $36,37,55,56$

Trigonometrie, 21, 35, 39

Trisection of angles, 28

Twysden, 59, 68, 69, 73

Varignon, 77

Vieta, I, 2, 25, 32, 33, 35, 39-

$4 \mathrm{I}, 45,63,67,7 \mathrm{O}, 7 \mathrm{I}$

Vlack, 65

Von Braunmühl, 39

Wadham College, 5, 53

Wallis, John, r, r9, 27, 33, 45, $57-59,63,64,66-74,79-81,86$
Walmesley, D. C., 79

Ward, Bishop, $\mathrm{r}_{3}$

Ward, John, 76

Ward, Seth, 55, 58, 60, 68, 73, 74,81

Watch-making, 18,50

Weber, W. E., 48

Weddle, 56

Wells, E., 76, 82

Wharton, 60

Whitlock, B., 8, 9

Wilson, J., 77, 82

Wing, V., 73, 75

Wingate, E., 32, 47, 73

Wolf, Christian, 79

Wood, A., 6o, 6r

Wood, R., I8, 59

Wren, Christopher, $5,58,59,76$

Wright, E., 6, 27, 38, 54

Wright, S., 54 


$$
\text { - }
$$





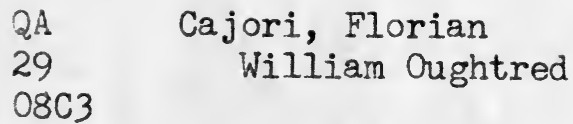

PEA SC:

\author{
PLEASE DO NOT REMOVE \\ CARDS OR SLIPS FROM THIS POCKET
}

UNIVERSITY OF TORONTO LIBRARY 
(I)

3. 